\title{
From BASE-ASIA toward 7-SEAS: A satellite-surface perspective of boreal spring biomass-burning aerosols and clouds in Southeast Asia
}

\author{
Si-Chee Tsay ${ }^{\mathrm{a}, *}$, N. Christina Hsu ${ }^{\mathrm{a}}$, William K.-M. Lau ${ }^{\mathrm{a}}$, Can $\mathrm{Li}^{\mathrm{a}}{ }^{\mathrm{a}}$, Philip M. Gabriel ${ }^{\mathrm{c}}$,
} Qiang Ji ${ }^{\mathrm{a}, \mathrm{b}}$, Brent N. Holben ${ }^{\mathrm{a}}$, E. Judd Welton ${ }^{\mathrm{a}}$, Anh X. Nguyen ${ }^{\mathrm{d}}$, Serm Janjai ${ }^{\mathrm{e}}$, Neng-Huei Lin ${ }^{f}$, Jeffrey S. Reid ${ }^{\mathrm{g}}$, Jariya Boonjawat ${ }^{\mathrm{h}}$, Steven G. Howell ${ }^{\mathrm{i}}$, Barry J. Huebert ${ }^{\mathrm{i}}$, Joshua S. Fu ${ }^{\mathrm{j}}$, Richard A. Hansell ${ }^{\mathrm{a}, \mathrm{b}}$, Andrew M. Sayer ${ }^{\mathrm{a}, \mathrm{k}}$, Ritesh Gautam $^{\mathrm{a}, \mathrm{k}}$, Sheng-Hsiang Wang ${ }^{\mathrm{f}}$, Colby S. Goodloe ${ }^{\mathrm{a}}$, Laddawan R. Miko ${ }^{\mathrm{a}}$, Peter K. Shu ${ }^{a}$, Adrian M. Loftus ${ }^{1}$, Jingfeng Huang ${ }^{\text {, }}{ }^{\text {, }}$, Jin Young Kim ${ }^{n}$, Myeong-Jae Jeong ${ }^{\mathrm{O}}$, Peter Pantina ${ }^{\mathrm{a}, \mathrm{p}}$

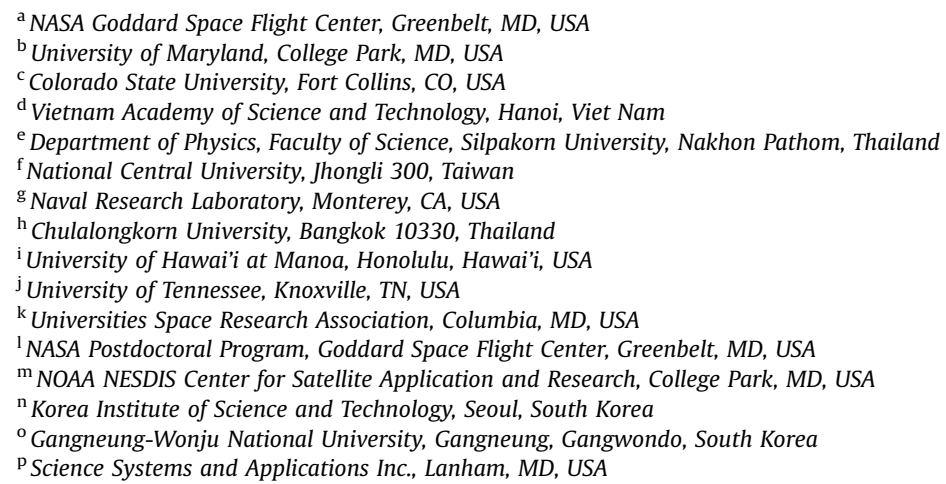

\section{H I G H L I G H T S}

- Multi-year, international efforts for studying aerosol and climate impacts across Southeast Asia.

- Aerosol and cloud properties measured from both ground- and satellite-based platforms.

- Investigation of aerosol-cloud interactions and planning for future experiments.

\section{A R T I C L E I N F O}

\section{Article history:}

Received 23 August 2012

Received in revised form

10 December 2012

Accepted 11 December 2012

\section{Keywords:}

Biomass-burning

Aerosol

Cloud

Southeast Asia

BASE-ASIA

7-SEAS

\section{A B S T R A C T}

In this paper, we present recent field studies conducted by NASA's SMART-COMMIT (and ACHIEVE, to be operated in 2013) mobile laboratories, jointly with distributed ground-based networks (e.g., AERONET, http://aeronet.gsfc.nasa.gov/ and MPLNET, http://mplnet.gsfc.nasa.gov/) and other contributing instruments over northern Southeast Asia. These three mobile laboratories, collectively called SMARTLabs ( $c f$. http://smartlabs.gsfc.nasa.gov/, Surface-based Mobile Atmospheric Research \& Testbed Laboratories) comprise a suite of surface remote sensing and in-situ instruments that are pivotal in providing high spectral and temporal measurements, complementing the collocated spatial observations from various Earth Observing System (EOS) satellites. A satellite-surface perspective and scientific findings, drawn from the BASE-ASIA (2006) field deployment as well as a series of ongoing 7-SEAS (2010-13) field activities over northern Southeast Asia are summarized, concerning (i) regional properties of aerosols from satellite and insitu measurements, (ii) cloud properties from remote sensing and surface observations, (iii) vertical distribution of aerosols and clouds, and (iv) regional aerosol radiative effects and impact assessment. The

\footnotetext{
* Corresponding author. NASA Goddard Space Flight Center, Code 613, Greenbelt, MD 20771, USA. Tel.: +1 3016146188 ; fax: +1 301 614 6307.

E-mail address: si-chee.tsay@nasa.gov (S.-C. Tsay).
} 
aerosol burden over Southeast Asia in boreal spring, attributed to biomass burning, exhibits highly consistent spatial and temporal distribution patterns, with major variability arising from changes in the magnitude of the aerosol loading mediated by processes ranging from large-scale climate factors to diurnal meteorological events. Downwind from the source regions, the tightly coupled-aerosol-cloud system provides a unique, natural laboratory for further exploring the micro- and macro-scale relationships of the complex interactions. The climatic significance is presented through large-scale anti-correlations between aerosol and precipitation anomalies, showing spatial and seasonal variability, but their precise cause-andeffect relationships remain an open-ended question. To facilitate an improved understanding of the regional aerosol radiative effects, which continue to be one of the largest uncertainties in climate forcing, a joint international effort is required and anticipated to commence in springtime 2013 in northern Southeast Asia. Published by Elsevier Ltd.

\section{Background and motivation}

Biomass burning has been a regular practice for land conversion and land clearing (e.g., deforestation, burning of secondary forests and pastures) in many countries, especially in the tropical areas of Africa, South America, and Asia (cf. Crutzen and Andreae, 1990; and references therein). Significant amounts of greenhouse gases (e.g., $\mathrm{CO}_{2}, \mathrm{CH}_{4}, \mathrm{~N}_{2} \mathrm{O}$ ), chemically active gases (e.g., $\mathrm{NO}, \mathrm{CO}, \mathrm{HC}$, and volatile organic compounds), and light-absorbing aerosols (e.g., elemental and organic carbon) are produced by the biomass-burning processes around the globe ( $c f$. Akagi et al., 2011; Reid et al., 2005a,b; and references therein). These trace gases and aerosols influence both atmospheric composition and regional-to-global climate (e.g., Andreae et al., 2005).

Biomass-burning activities in tropical and subtropical Africa persist year round (cf. Swap et al., 2003; Giglio et al., 2006; and references therein). Over Amazonia and nearby regions in South America, the annual mean of aerosol loading is dominated by biomass-burning emissions ( $c f$. Martin et al., 2010; Yokelson et al., 2007; and references therein). Compared to these two regions, biomass burning related studies over tropical Asia are underrepresented in the literature ( $c f$. Reid et al., 2012 for a broad review). Recently, Lawrence and Lelieveld (2010) presented a comprehensive review of outflow of South Asian aerosols toward the surrounding oceanic regions. Based on satellite data, biomass-burning emissions were estimated (e.g., Chang and Song, 2010) in tropical Asia, extending from India/Nepal southeastward to Indonesia. However, during the boreal spring peak-burning season, the climatology of Southeast Asia is very different from that of Africa or South America. Large-scale biomass burning causes smoke aerosols to extend throughout a deep layer, overlying and overlapping with a quasi-stationary stratocumulus cloud band stretching over vast distances, as observed by satellite sensors. Smoke particles have long been recognized as effective cloud condensation nuclei (e.g., Reid et al., 2005a). They are particularly active at lower levels of supersaturation, such as those occurring in stratocumulus clouds, where aerosol-cloud interactions are most favored (e.g., Sorooshian et al., 2009). By comparison to the ship track environment (e.g., Durkee et al., 2000), Southeast Asia in the spring, acting as a regional scale natural laboratory, is best for exploring the complex aerosol-cloud-water cycle interactions under active stratiform convection. This condition permits field measurements to go a long way toward validating results from satellite observations, as well as allowing for a better understanding of atmospheric processes through comprehensive modeling efforts.

Two grass-root projects, the 2006 BASE-ASIA (Biomass-burning Aerosols in South East Asia: Smoke Impact Assessment) and the ongoing 2008-2013 7-SEAS (Seven South East Asian Studies), were conceived expressly for the purpose of quantifying aerosol/cloud properties and probing their interactions. Participants in the BASEASIA campaign include the Southeast Asia START (SysTem Analysis,
Research and Training) regional center based at Chulalongkorn University, NASA Goddard Space Flight Center, and the University of Hawaii. The campaign was designed to: (i) increase understanding of the effects of biomass-burning aerosols on remote sensing observations of the atmosphere, (ii) characterize and assess the radiative effects of biomass-burning aerosols on the regional Earthatmosphere system and the impact to global climate, and (iii) provide educational opportunities for regional scientists and graduate students who desire additional training and research experience ( $c f$. Fig. $\mathrm{S} 1)$.

Continuing the quest for a deeper understanding of the way aerosols affect Southeast Asian weather, climate, and the environment, the ongoing 7-SEAS project integrates an international effort involving Indonesia, Malaysia, Philippines, Singapore, Taiwan, Thailand, Vietnam, and the United States (NASA and the Office of Naval Research) in forming a highly interdisciplinary science team. Research topics include seven focus areas from which the program derives its name: (1) clouds and precipitation, (2) radiative transfer, (3) anthropogenic and biomass-burning emissions and evolution, (4) natural background atmospheric chemistry, (5) tropicalsubtropical meteorology (6) regional nowcasting, forecasting, and inter-annual/climate outlooks, and (7) satellite and model calibration/validation. Thus, to attain the scientific goals of the 7-SEAS project, extended measurement and analysis periods (i.e., 20082013) of the regional Earth-atmosphere system are required. On short time scales, focusing on smaller Intensive Observational Periods (IOPs) would foster the development and refinement of scientific hypotheses that can be investigated in larger field campaigns, as well as advancing the development of an effective and collaborative science team, thus promoting true international partnerships. The first pilot IOP of 7-SEAS was conducted at Dongsha Island (e.g., Wang et al., 2011), with participation of NASA SMARTLabs and Taiwan EPA mobile laboratory, for studying aerosol properties at the downwind/sink region in March-June 2010. Whereas the follow-up IOP was conducted in the spring of 2011, participation by NASA scientists began in 2012, in collaboration with science teams from Taiwan and Vietnam in two consecutive IOPs at Son La, Vietnam for studying aerosol properties along the pathway of long-range transport. In addition, five sets of thermal-dome-effect corrected pyranometers (Ji and Tsay, 2010; Ji et al., 2011) and pyrgeometers were deployed to take measurements of surface irradiance, collocated with AERONET sunphotometer observations, at Silpakorn University (Thailand), Luang Namtha (Laos), Son La (Vietnam), Dongsha (Taiwan), and Gangneung (South Korea), throughout the spring 2012 campaign. The network measurements captured the spatiotemporal evolution of surface radiative energetics, which can be compared to and used in conjunction with satellite measured/ retrieved irradiances for investigating changes in column energy distribution due to aerosol/cloud perturbations.

In this overview paper, we will review and discuss results from papers published in this special issue and other journals using both 
BASE-ASIA/7-SEAS IOP data and satellite measurements, as well as model simulations. We begin in Section 2 by describing the observation activities of the 2006 BASE-ASIA in Thailand and ongoing 2010-2013 7-SEAS campaigns over northern Southeast Asia. Section 3 summarizes the scientific findings, concerning (i) regional aerosol properties from satellite and in-situ measurements, (ii) cloud properties from remote sensing and surface observations, (iii) vertical distribution of aerosols and clouds and their interactions, and (iv) regional aerosol radiative effects and impact assessment. The concluding remarks and future work are given in Section 4.

\section{Observation activities}

Regional biomass-burning activities are influenced by various factors, ranging from large-scale climatic variations such as the El Niño/La Niña-Southern Oscillation (ENSO), seasonal cycles and natural year-to-year variability, to diurnal time-scale weather patterns. These meteorological processes modulate biomass-burning emissions by altering the precipitation, soil moisture content, and transport mechanism via varying the atmospheric circulation. Long-term satellite observations during 1997-2010 using NASA Sea-viewing Wide Field-of-view Sensor (SeaWiFS) revealed no discernible trend in the springtime (March, April, and May) aerosol loading over Southeast Asia, although clouds often obstruct the view of satellites over the region, making meaningful trend analysis difficult (Hsu et al., 2012). To facilitate a statistically significant comparison, we relate the monthly biomass-burning carbon emissions over Southeast Asia (GFED V3, Global Fire Emissions Database, van der Werf et al., 2010) to the corresponding monthly mean precipitation (GPCP V2.2, Global Precipitation Climatology Project, Adler et al., 2003). GFED emission estimates were based on satellite-retrieved burned area and biogeochemical model simulations, while GPCP combines data from both satellites and the surface rain gauge networks. As shown in Fig. 1, biomass-burning emissions and precipitation over Southeast Asia both demonstrate sizable inter-annual variability. Biomass burning always peaks in March, and years receiving less precipitation during this month normally see much stronger emissions. Precipitation becomes more intense in April, near the onset of the Asian summer monsoon. ENSO is one of the prominent systems influencing the development of the Asian monsoon and precipitation in the region (Lim and Kim, 2007), and likely has contributed to the five strongest biomass-burning years during this period (1998/1999, 2004, 2007, and 2010). With the exception of 2004, which was a weak El Niño year, the other four years all exhibited relatively dramatic transitions from El Niño to La Niña conditions. Lim and Kim (2007) also noted that other phenomena, such as the regional-scale intraseasonal oscillations, might influence the development of the Asian monsoon as well as biomass-burning emissions from Southeast Asia. On the contrary, 2006 was among the lowest years in biomass burning emissions, attributed to unseasonable rain caused by tropical cyclone Mala in late April and to the earlier start of rainy season over Southeast Asia.

The BASE-ASIA campaign was conducted from late February to early May during the dry season of 2006. Within this time frame, the operational polar-orbiting satellites/sensors of SeaWiFS, TRMM, Terra, EO-1, Aqua, ICESat, OMI and POLDER (cf. http://eospso.gsfc. nasa.gov/, EOS Mission Profiles for details of satellite and instrumentation), provided comprehensive measurements of regional aerosol and cloud properties. Measurements from these sensors have produced retrievals of intrinsic properties of the atmosphere (e.g., trace-gas abundance, temperature/moisture profiles, aerosol loading and size distribution, optical thickness and size/phase of clouds, precipitation, top-of-atmosphere irradiance, etc.) at known levels of confidence. Space-borne remote sensing observations, however, are often plagued by contamination introduced by naturally occurring signals emanating from the surface. Thus, groundbased in-situ and remote sensing measurements, where signals originate directly from atmospheric constituents, the Sun, and/or Earth-atmosphere interactions, provide additional information for comparisons that confirm quantitatively the usefulness of the integrated surface, aircraft, and satellite datasets. The ground-based site of BASE-ASIA was located at Phimai, a vast plain with agricultural settings in central Thailand. SMARTLabs' SMART (Surfacesensing Measurements for Atmospheric Radiative Transfer), COMMIT (Chemical, Optical \& Microphysical Measurements of In-situ Troposphere) and U. Hawaii's instruments (cf. Fig. S2) were deployed at the Phimai observatory and radar station $\left(15.18{ }^{\circ} \mathrm{N}\right.$, $102.56^{\circ} \mathrm{E}, 206 \mathrm{~m}$ above sea level), operated by the Bureau of Royal Rainmaking and Agricultural Aviation, Thailand. At the beginning of the BASE-ASIA campaign, this site was largely under the influence of dry-cool northeast monsoon (nominally from mid-October to mid-February) and later was dominated by the wet-warm southwest monsoon (mid-May to mid-October). As a result, aerosols from various sources including biomass-burning smoke,

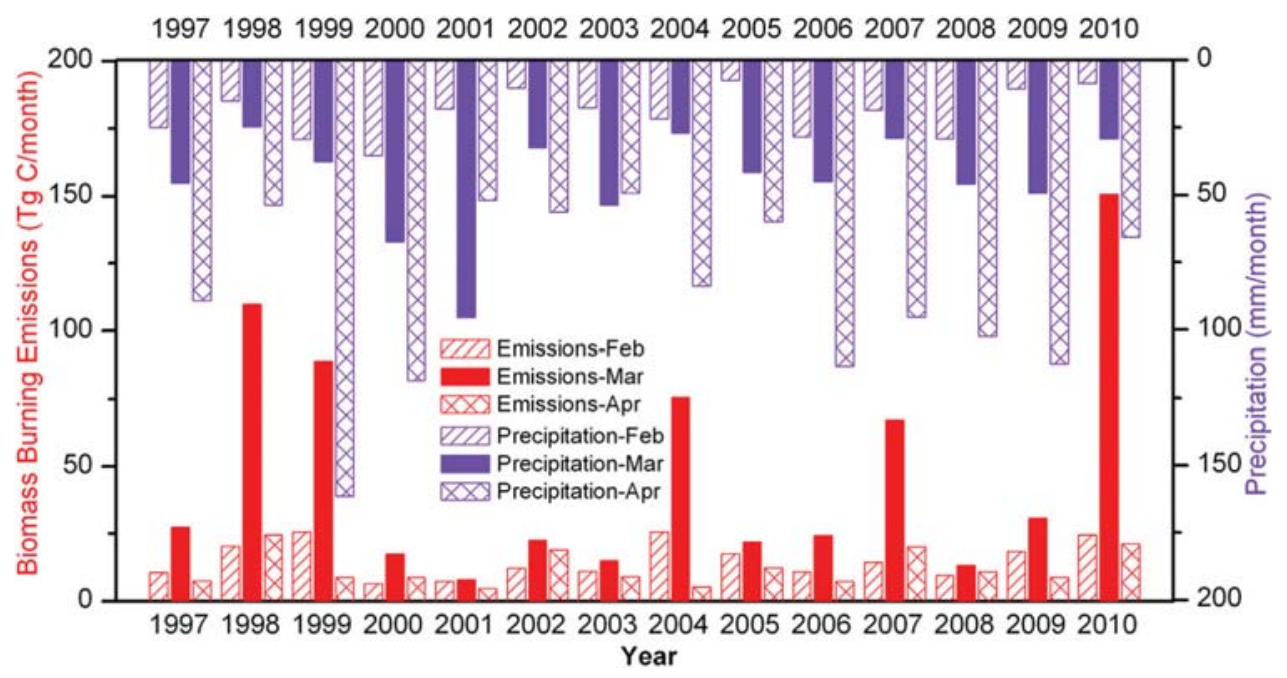

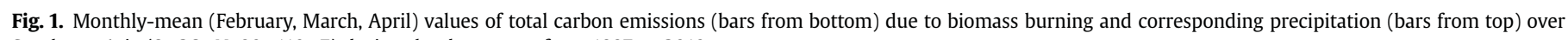
Southeast Asia $\left(8-26^{\circ} \mathrm{N}, 90-110^{\circ} \mathrm{E}\right)$ during the dry season from 1997 to 2010. 
anthropogenic emissions, and transboundary transport were measured during the experiment.

Table S1 lists the remote sensing and in-situ instruments deployed during the BASE-ASIA campaign from which, and for the first time in the region, comprehensive surface observations of aerosols and clouds were produced. Like Angkor Wat, the great solar observatory (cf. http://sunearthday.nasa.gov/2005/locations/ angkorwat.htm) of the ancient Khmer Empire in Southeast Asia, the modern Phimai Observatory, hosting a sunphotometer as a part of NASA/AERONET global operations (Holben et al., 1998) since 2003, has archived the earliest running sunphotometry measurements in the region. After the completion of the 2006 BASE-ASIA campaign, AERONET's expanded collaboration with Silpakorn's Solar Radiation Monitoring Network (cf. Fig. S3 and Janjai et al., 2009, 2012), led to the extended regional coverage of sunphotometry observations over Laos, Myanmar, and Thailand. Furthermore, SKYNET ( $c f$. http://atmos.cr.chiba-u.ac.jp/) has also been operating at the Phimai Observatory since 2005, as part of a regional network for studying aerosol-cloud-radiation interactions. The main instruments employed by SKYNET consist of a sky radiometer (Sano et al., 2003) and basic radiation instruments such as pyranometer and pyrgeometer. Since late 2006, as a consequence of its collaborative efforts with Project ABC (Atmospheric Brown Clouds; Ramanathan and Crutzen, 2003), the Phimai Observatory has become the sole ABC climate observatory in Southeast Asia.

In addition to the aforementioned activities, a special dataset from the Virtual Biomass Burning Experiment (cf. http://www. nrlmry.navy.mil/aerosol/7seas/), designated as the 7-SEAS warmup exercise, was collected and archived productively to cover the entire month of August in 2007 over Southeast Asia. Subsequently from 2010 to 2012, a series of pilot IOPs in the northern regions of the 7-SEAS domain were successfully conducted at Dongsha Island, Taiwan (cf. http://aerosol.atm.ncu.edu.tw/DongSha/; Wang et al., 2011) and at Son La, Vietnam (cf. http://aerosol.atm.ncu.edu.tw/ SonLa/; and Lin et al., 2013 for more details) over the boreal spring biomass-burning seasons. Although a few satellites (e.g., ICESat, SeaWiFS) reached the end of their lifetime since 2006 BASEASIA, new ones (e.g., CALIPSO, CloudSat, Suomi NPP) with enhanced capabilities have been introduced. Complementing satellite observations, the latest addition of ACHIEVE (Aerosol-CloudHumidity Interaction Exploring \& Validating Enterprise, $c f$. Fig. S4) to the SMARTLabs facility contains state-of-the-art active/passive sensors for probing the atmosphere. In conjunction with satellite overpasses, the strategic deployments of SMARTLabs facility combined with distributed networks (e.g., AERONET/MPLNET) and regional measurements ( $c f$. Fig. 2) near/downwind of aerosol source regions and along transport pathways, offer a synergistic approach for further exploring many key atmospheric processes (e.g., spatiotemporal evolution of aerosols, precursor gases and complex aerosol-cloud interactions). Table S2 summarizes the instrumentation for the 7-SEAS deployments in the northern regions of Southeast Asia during the 2010-2012 and upcoming 2013 campaigns. Additional studies of chemical species (e.g., reactive mercury, dioxins and organic acids associated with biomass burning) were also (and will be) undertaken. Such analyses are rarely performed in Southeast Asia, particularly through a network approach. More detailed discussions of the instrumentation, site topology, and scientific background for the investigation can be found in Lin et al. (2013) as well as other studies in this special issue.

\section{Scientific findings}

Solar radiation is the sole large-scale source of diabatic heating that drives the terrestrial weather and climate systems. The states of these systems are, in part, characterized by the microphysical, chemical, and optical properties of aerosols and clouds in their horizontal as well as vertical distributions in the atmosphere. Perturbations from their mean values alter the system's energetics and may herald a change of state. Inferences of the aforementioned properties through measurements and time series analyses of their occurrences hold the keys to understanding aerosol-cloudradiation interactions and the hydrological cycle ( $c f$. Lau and Yang, 1997; and references therein). These phenomena are large and fundamental components of the Earth-atmosphere system that are being perturbed by anthropogenic emissions of aerosols and radiatively active trace gases into the atmosphere. Thus, in addition to being scientifically interesting in their own right, understanding aerosol-cloud-water cycle interactions has bearing on human welfare.

\subsection{Aerosol loading and in-situ measurements}

On an annual basis, the northern region of Southeast Asia experiences widespread emissions of biomass-burning aerosols resulting from the combustion of organic matter due to deforestation and agricultural practices (e.g., van der Werf et al., 2010). These emissions tend to peak in March, resulting in elevated aerosol loadings in the boreal spring (Streets et al., 2003). Fig. 3 shows examples of monthly averaged mid-visible aerosol optical thickness (AOT) derived from the MODerate-resolution Imaging Spectroradiometer (MODIS) aboard the EOS/Terra satellite. Data from the Collection 5.1 algorithms are shown in Fig. 3; the forthcoming Collection 6 will incorporate refinements to algorithms and calibration, including the extension of the Deep-Blue AOT retrieval

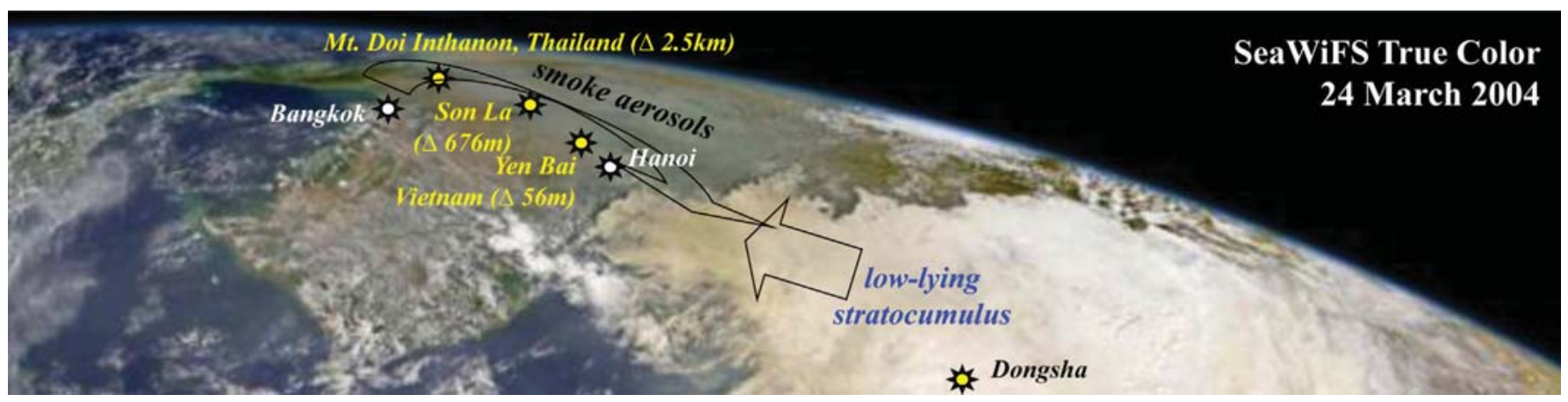

Fig. 2. Synergistic deployment of SMARTLabs mobile laboratories (yellow markers) with regional network observations in 2010-2013, in northern Thailand/Lao/Vietnam near source regions and along transport pathways of biomass-burning aerosols and at downwind cloudy areas in northeastern Vietnam and SCS/ES, to study the evolution of atmospheric composition of springtime biomass-burning aerosols and complex aerosol-cloud interactions over northern Southeast Asia in 7-SEAS. 

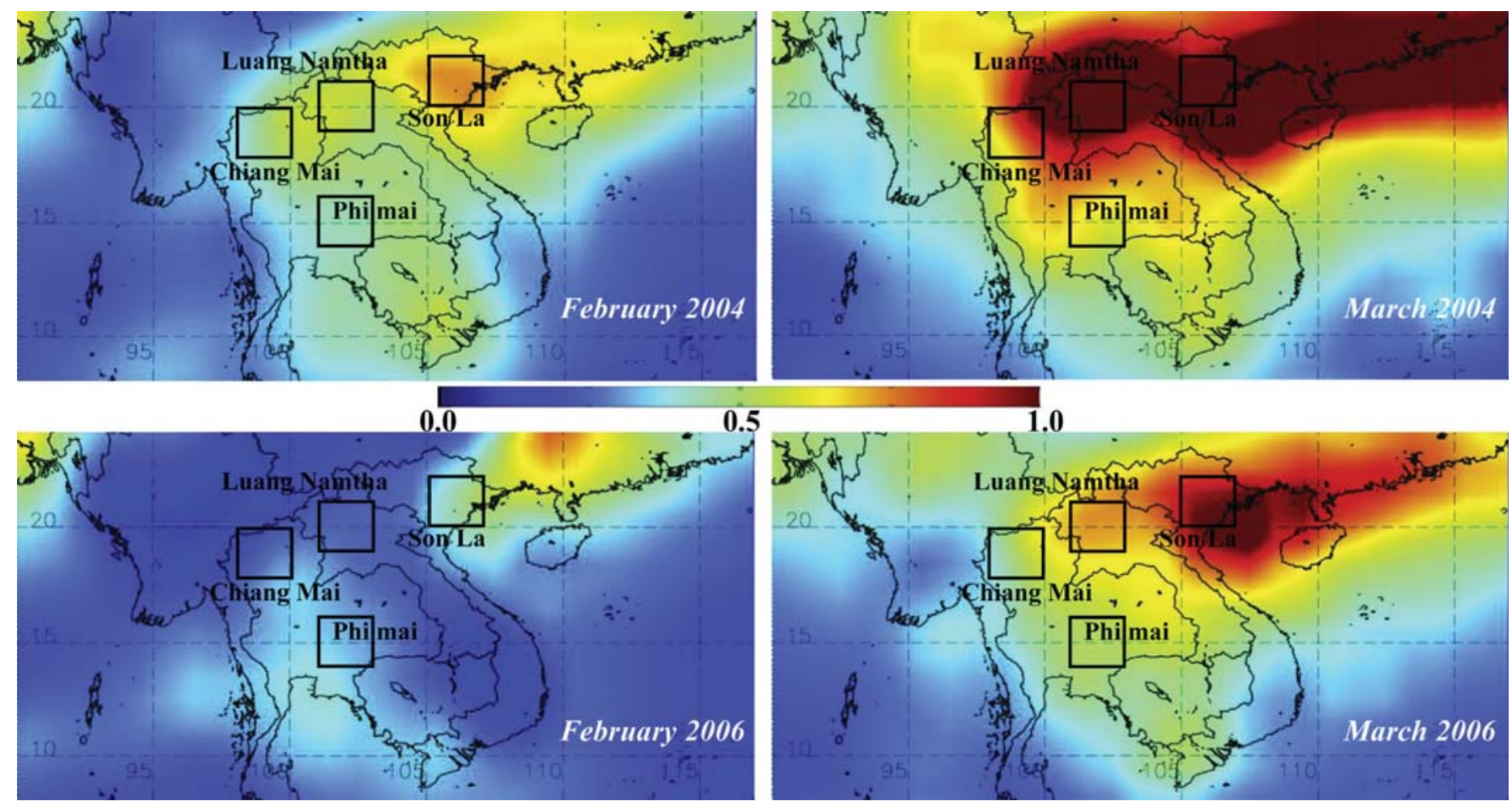

Fig. 3. Monthly-mean AOT at $550 \mathrm{~nm}$ from MODIS/Terra over Southeast Asia, shown data for February (left column) and March (right column) of 2004 (top row) and 2006 (bottom

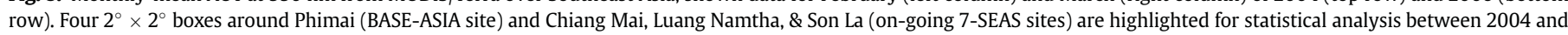
2006.

algorithm (Hsu et al., 2004, 2006) from arid surfaces only to both arid and vegetated land surfaces. This will enable, for many locations, analysis of AOT determined by both the Deep-Blue and DarkTarget (Levy et al., 2007) algorithms.

Four regions within Fig. 3 are highlighted: Chiang Mai (Thailand), Luang Namtha (Laos), Son La (Vietnam) and Phimai (Thailand). Chiang Mai is near strong aerosol sources, while Luang Namtha and Son La are progressively farther downwind and at lower altitudes, such that the transported aerosol has aged (and may also contain contributions from local sources). These four regions are parts of the aerosol observational sites for the ongoing 7SEAS IOPs, except for Phimai, which was studied extensively during BASE-ASIA and is away from this transport route in representing more background conditions. Table 1 provides comparative MODISderived AOT for these regions in February and March of 2004 and 2006 for contrasting purposes. The March maximum observed at these locations is mirrored over most of the region. The AOT in March was also higher in 2004 than in 2006 (the BASE-ASIA year), linked with the lower precipitation and higher biomass-burning emissions in 2004 ( $c f$. Fig. 1), although the spatial patterns are similar. MODIS-derived AOT and the statistical variability of this

Table 1

Monthly mean values and day-to-day standard deviation of AOT at $550 \mathrm{~nm}$ wavelength from MODIS/Terra, for four regions within Fig. 3.

\begin{tabular}{|c|c|c|c|c|}
\hline \multirow[t]{2}{*}{ Region } & Chiang Mai & Luang Namtha & Son La & Phimai \\
\hline & $\begin{array}{l}18-20^{\circ} \mathrm{N} \\
98-100^{\circ} \mathrm{E}\end{array}$ & $\begin{array}{l}19-21^{\circ} \mathrm{N}, \\
101-103^{\circ} \mathrm{E}\end{array}$ & $\begin{array}{l}20-22^{\circ} \mathrm{N}, \\
103-105^{\circ} \mathrm{E}\end{array}$ & $\begin{array}{l}14-16^{\circ} \mathrm{N}, \\
101-103^{\circ} \mathrm{E}\end{array}$ \\
\hline \multicolumn{5}{|l|}{2004} \\
\hline February & $0.44 \pm 0.28$ & $0.52 \pm 0.34$ & $0.56 \pm 0.28$ & $0.41 \pm 0.24$ \\
\hline $\begin{array}{l}\text { March } \\
2006\end{array}$ & $0.78 \pm 0.31$ & $1.19 \pm 0.35$ & $1.23 \pm 0.41$ & $0.52 \pm 0.24$ \\
\hline February & $0.22 \pm 0.16$ & $0.23 \pm 0.11$ & $0.28 \pm 0.16$ & $0.31 \pm 0.15$ \\
\hline March & $0.52 \pm 0.28$ & $0.75 \pm 0.29$ & $0.76 \pm 0.28$ & $0.47 \pm 0.19$ \\
\hline
\end{tabular}

quantity exhibit strong similarities for Luang Namtha and Son La. In these two regions, the AOT exceeds unity during March 2004, significantly greater than that over either Chiang Mai or Phimai. The large standard deviations reveal considerable variability in the dayto-day aerosol burden, particularly in the high-AOT months, suggesting some typical background aerosol loading punctuated by high-AOT biomass-burning events. Spatial and seasonal variations in AOT from MODIS/Aqua are similar. In addition, Gautam et al. (2013) also analyzed the relationship between seasonal aerosol loading and biomass-burning activities, as observed in the interannual variations of AOT and fire counts from MODIS, averaged over the northern region of Southeast Asia (Myanmar, Thailand, Laos) from 2001 to 2010. The MODIS-detected fire activity peaked strongly during the February-April period and was well correlated $\left(r^{2}=0.66\right)$ with AOT, suggesting smoke due to forest fires and agricultural crop burning as the major contributions to the seasonal aerosol burden.

Although the analyses of the physical and chemical properties of aerosols based on in-situ measurements from 2010 to 2012 IOPs near source regions and along transport pathways are still largely in progress ( $c f$. Lin et al., 2013), Li et al. (2013) presented a comprehensive study using measurements made in Phimai during the 2006 BASE-ASIA field campaign. Sizable aerosol loading was measured; the mean aerosol scattering and absorption coefficients $(\lambda=0.55 \mu \mathrm{m})$, and $\mathrm{PM}_{10}$ concentration were $108 \pm 64 \mathrm{Mm}^{-1}$, $15 \pm 8 \mathrm{Mm}^{-1}$, and $33 \pm 17 \mu \mathrm{g} \mathrm{m}^{-3}$, respectively. Due to prevalent agricultural fires in the area, carbonaceous aerosols were the most abundant species (organic carbon, OC: $9.5 \pm 3.6 \mu \mathrm{g} \mathrm{m}^{-3}$; elemental carbon, EC: $2.0 \pm 2.3 \mu \mathrm{g} \mathrm{m}^{-3}$ ). The concentration of water-soluble $\mathrm{K}^{+}$, a tracer for biomass-burning emissions, reached $0.56 \pm 0.33 \mu \mathrm{g} \mathrm{m}^{-3}$. On the other hand, even for this relatively remote rural site, industrial and other anthropogenic sources exert, nevertheless, substantial impact on aerosol pollution, as suggested by the loadings of $\mathrm{SO}_{4}{ }^{2-}\left(6.4 \pm 3.7 \mu \mathrm{g} \mathrm{m}^{-3}\right), \mathrm{NH}_{4}{ }^{+}\left(2.2 \pm 1.3 \mu \mathrm{g} \mathrm{m}^{-3}\right)$, 
and $\mathrm{NO}_{3}{ }^{-}\left(1.0 \pm 0.8 \mu \mathrm{g} \mathrm{m}^{-3}\right)$. The humid environment in Phimai was important in determining the regional aerosol composition and properties. The size distribution and diurnal change of sulfate suggested active aqueous phase reactions, and hygroscopic growth of particles has the propensity of enhancing the aerosol light scattering by about $20 \%$. Enhancement was observed to be much stronger in the morning, leading to diurnal variation in the single-scattering albedo of aerosols $(0.86 \pm 0.04$ to $0.92 \pm 0.02)$. Gautam et al. (2013) extended the study of the diurnal pattern beyond the 2006 BASE-ASIA deployment to cover different regions in Thailand. The direct sun measurements from AERONET for the peak smoke-laden period (March-April) in years 2007-2009 at Chiang Mai, Mukdahan, Phimai and Silpakorn University revealed similar diurnal patterns and values of aerosol single-scattering albedo. Overall, results from the BASE-ASIA experiment indicate that aerosol pollution might have developed into a regional issue for northern Southeast Asia (Li et al., 2013), and may become more severe in the future.

During the spring 2010 of 7-SEAS, comprehensive measurements (Wang et al., 2011) of aerosols and trace gases were acquired at Dongsha $\left(20.70{ }^{\circ} \mathrm{N}, 116.73{ }^{\circ} \mathrm{E}\right.$, or Pratas Islands), an atoll located in northeastern South China Sea (or East Sea; hereafter referenced as SCS/ES) and downwind of seasonal monsoon flows. Between March 10 and May 19, the mean concentrations of $\mathrm{CO}, \mathrm{O}_{3}$, and $\mathrm{PM}_{10}$ were $237.9 \pm 70.0 \mathrm{ppbv}, 42.0 \pm 14.6 \mathrm{ppbv}$, and $30.2 \pm 17.5 \mu \mathrm{g} \mathrm{m}^{-3}$, respectively. Temporal variations of pollutants related to source origins and transport processes were strongly dominated by meteorological dynamics. Two independent studies (Atwood et al., 2013; Wang et al., 2013) using coincident measurements of aerosol properties revealed that the northeastern SCS/ES exhibits a strong marine aerosol signature mostly confined inside the boundary layer $(\sim 1 \mathrm{~km})$ consisting of sea-salt, dust and pollution, along with upper-level aerosols, related to biomass-burning smoke from Southeast Asia, found above the inversion ( $2-4 \mathrm{~km})$. Compositional analysis of surface observed aerosol species yields convincing evidence that crustal elements are associated with dust and heavy metals tied to industrial pollution, whereas chlorine and magnesium are related to sea salt. The high aerosol hygroscopicity $\left(f_{80 \%}\right.$ : 1.8 , or $f_{85 \%}: 2.1$ ) also suggests a mixture of anthropogenic and marine aerosols.

Back trajectory analyses showed transported air masses ( $~ 52 \%)$ were generally dominated by low-level flows from continental and coastal regions north of the SCS/ES, including the major dust source regions in northwest China (i.e., Taklamakan and Gobi deserts), while upper-level transport of aerosols was found to have originated from Southeast Asia. Aerosols of continental origin have higher mass concentrations $\left(\mathrm{PM}_{10}: 37.7 \pm 17.1 \mu \mathrm{g} \mathrm{m}{ }^{-3}\right)$, scattering $\left(\beta_{\mathrm{s}}: 72.4 \pm 33.2 \mathrm{Mm}^{-1}\right)$, absorption $\left(\beta_{\mathrm{a}}: 4.4 \pm 2.7 \mathrm{Mm}^{-1}\right)$ and extinction $\left(\beta_{\mathrm{e}}: 76.8 \pm 34.9 \mathrm{Mm}^{-1}\right)$, and single-scattering albedo $(\omega$ : $0.94 \pm 0.03$; all at $\lambda=0.55 \mu \mathrm{m})$, than those associated with aerosols of oceanic origin $\left(\mathrm{PM}_{10}: 22.0 \pm 14.0 \mu \mathrm{g} \mathrm{m} \mathrm{m}^{-3} ; \beta_{\mathrm{s}}\right.$ : $53.1 \pm 29.7 \mathrm{Mm}^{-1} ; \beta_{\mathrm{a}}: 5.4 \pm 3.5 \mathrm{Mm}^{-1} ; \beta_{\mathrm{e}}: 58.5 \pm 30.9 \mathrm{Mm}^{-1} ; \omega:$ $0.90 \pm 0.07$ ). Note that aerosols having pure oceanic origin (e.g., sea-salt) typically exhibit much higher values of $\omega$ (e.g., $\sim 0.99$ reported in Anderson et al., 1999). Hence, the values derived in Wang et al. (2013) reflect marine aerosol mixtures containing anthropogenic components with stronger absorption, such as EC. Air masses with trajectories characterized by easterly/southerly paths over maritime continents (i.e., the Philippines), exhibited higher fractions of EC than aerosols of continental origin ( $4 \%$ vs. $3 \%$, Chuang et al., 2013). Emissions from local shipping activities, mostly fishing, are small, although could contribute to the observed reductions in scattering. Nevertheless, this study uses the term "oceanic" to distinguish these aerosols from those of continental origin. The lack of a potassium signal, a common tracer for smoke, in the surface measurements together with clear upper- level features observed in the lidar normalized relative backscatter (NRB) profiles and simulations from diagnostic/prognostic models (e.g., Navy Aerosol Analysis and Prediction System, NAAPS, and Navy Operational Global Atmospheric Prediction System, NOGAPS, used in Atwood et al., 2013), strongly suggest the presence of smoke aerosols above the marine boundary layer. This multilayer distribution of aerosols has important implications on remote sensing and retrievals, radiation budget, and aerosol-cloudradiation interactions.

For years, the aerosol community has been grappling with the ill-posed problem of bridging together the modeling and observational perspectives of aerosol optical properties and how these relate to their mass. Solutions to these difficult problems are vitally important, particularly in remote sensing and climate studies of the Earth-atmosphere system. With continued advancements in instrumentation and modeling, optical closure experiments are becoming increasingly more successful and key optical parameters (e.g., mass extinction efficiencies) are becoming better characterized. Although important for studies on visibility reduction and air quality, many of the recent efforts have only focused on the light scattering properties of aerosols. There is still a large need to characterize the spectral absorbing properties of aerosols, particularly for heavy aerosol-laden regions, and the impact they have on the energetics of the atmosphere. The site of 7-SEAS/Dongsha is located at a convergence zone for many different aerosol types including pollution, smoke, dust and sea-salt. Achieving optical consistency at this dynamic location will ultimately benefit future radiative and climate studies.

Bell et al. (2013) attempted optical closure for both scattering and absorption using SMARTLabs-COMMIT measurements taken during the Dongsha experiment at in 2010. Imperative to this study was the use of an IMPROVE (a modified Interagency Monitoring of PROtected Visual Environments) chemical sampler and joint microphysical measurements to help constrain aerosol composition and particle size in an optical model, from which the derived and measured optical parameters were compared. Given the assumptions required for partitioning the data, the model demonstrated skill in identifying peak aerosol events and transitions between key aerosol types. Atwood et al. (2013) also observed similar aerosol components at Dongsha using a collocated 8-stage DRUM (Davis Rotating-drum Uniform size-cut Monitor) sampler. Transitions from heavily polluted aerosols composed mostly of ammonia and non sea salt sulfate mixed with dust to mainly sea salt were more evident in absorption, due to the large variability in the imaginary component of the refractive indices. Scattering is shown to be negatively biased owing to the dry particle assumption employed in the study. In contrast, absorption agreed reasonably well with the measurements, with noted scatter for higher observed absorption values. This variability was attributed to initializing the model with an excess amount of soot or from the assumption that the aerosol mass across all particle size bins is equal. Instrumental limitations make it difficult to achieve full optical closure for a complex environment like Dongsha. However, given these limitations, the ability to track the changing optical properties of aerosols lends support to the consistency of groundbased measurements by COMMIT and demonstrates the utility that these measurements have for advancing climate research studies.

\subsection{Cloud properties from remote sensing and surface observations}

During boreal spring, two prominent cloud features in Southeast Asia are the widespread, persistent occurrence of thin cirrus clouds and quasi-stationary stratocumulus cloud bands stretching over vast expanses northwestwards from northern SCS/ 
ES to southeast China. Cirrus clouds play a critical role in modulating the radiation budget of the Earth-atmosphere system through the solar-albedo and infrared-greenhouse effects which are determined by the fundamental scattering and absorption properties of the complex microstructure among ice crystals (e.g., size and shape distributions) and large variability in cloud optical thickness (e.g., Stephens et al., 1990). Consequently, the net effect of cirrus clouds on the radiation budget and its climatic feedback are highly uncertain. Further complicating the issues in the region, thin cirrus clouds aloft often co-exist with smoke aerosols. To avoid biases introduced by the presence of cirrus clouds, rigorous cloud screening schemes are of paramount importance for accurate remote sensing and retrievals of aerosol properties, as well as quantifying the effects of aerosols on climate forcing. The susceptibility of ground-based and satellite aerosol retrievals to thin cirrus contamination (Huang et al., 2011) was examined comprehensively using concurrent aerosol (AERONET and MODIS) and cirrus observations (MPLNET and MODIS) at Phimai during the 2006 BASE-ASIA campaign. Results reveal that current operational AERONET and MODIS AOT products may still have residual thin cirrus contamination with strong seasonality. At Phimai during the late spring, cirrus clouds contaminated $\sim 20 \%$ of AOT retrievals, increasing their monthly means values by about $5 \%$. Consequently, caution must be exercised, and careful evaluation of the effects by thin cirrus contamination must be considered, before retrieved AOT values are used in aerosol-related climatic forcing studies.

Ubiquitous low-level stratiform clouds exert a net radiative cooling effect on the Earth-atmosphere system by scattering solar radiation back to space. Klein and Hartmann (1993) identified ten regions of active stratiform convection globally, in which the formation of stratiform clouds occurs predominantly over Earth's oceans with the exception of those over northern SCS/ES that extend deeply into the southeastern plains of China. Lower sea surface temperatures (SST) coupled with strong temperature inversions confine these clouds inside the marine boundary layer. Seasonal variability in the fraction of these clouds is inextricably linked to the static stability of the atmosphere, more so than any other thermodynamic or dynamic parameters. As static stability or inversion strength increases, marine stratiform convective processes dominate (e.g., December-March), characterized by strong surface divergence and relatively cooler SST; however, with warmer SST, the inversion strength is reduced, surface convergence increases, and cumulus convective processes dominate (e.g., May-August). During the winter months and early spring season, the fraction of stratiform clouds is nearly $50 \%$ and is linked to lower tropospheric stability. Stronger wintertime stratiform clouds for this region are associated with a local Hadley circulation (Klein and Hartmann, 1993) where strong subsidence is found over a surface high-pressure system that extends throughout southeastern China. With the onset of the monsoon season, moist southerlies converge just off SCS/ES, which leads to deep convection.

To maximize the observational efficiency of the planned 7-SEAS campaign in 2013 for studying aerosol-cloud interactions over northern Southeast Asia, instruments should be deployed strategically in areas where the seasonal biomass-burning aerosols and the stratocumulus clouds frequently overlap and interact with each other. Such areas are sometimes clearly visible near the western edge of these pre-monsoon clouds in satellite images, as depicted in Fig. 4a. To objectively determine the potential sites for the field experiment, we analyzed the cloud products retrieved from MODIS/Terra during spring (February to May) 2005-2009. For each day, the MODIS Collection 5 Level-2 cloud fraction (CF, range: $0-1,1$ corresponds to fully overcast sky conditions) product at $5 \times 5 \mathrm{~km}^{2}$ spatial resolution was first binned into $0.1^{\circ} \times 0.1^{\circ}$ grid cells. The gradient in CF was then calculated, since the edge of the cloud band for a particular day is often associated with cells of large CF gradient $(\geq 0.4)$. Repeating the process for the 5 -year period, and for each grid cell, the occurrences of large CF gradient values can be counted. As shown in Fig. 4b, areas in northern Vietnam and in central Vietnam near the border with Laos have the greatest occurrence of high CF gradients. Further examination of the terrain in the region suggests that the pre-monsoon cloud bands are primarily made up of low-level stratocumuli that are often blocked by the northsouth mountain range (elevation: $1-2 \mathrm{~km}$ ). These results agree
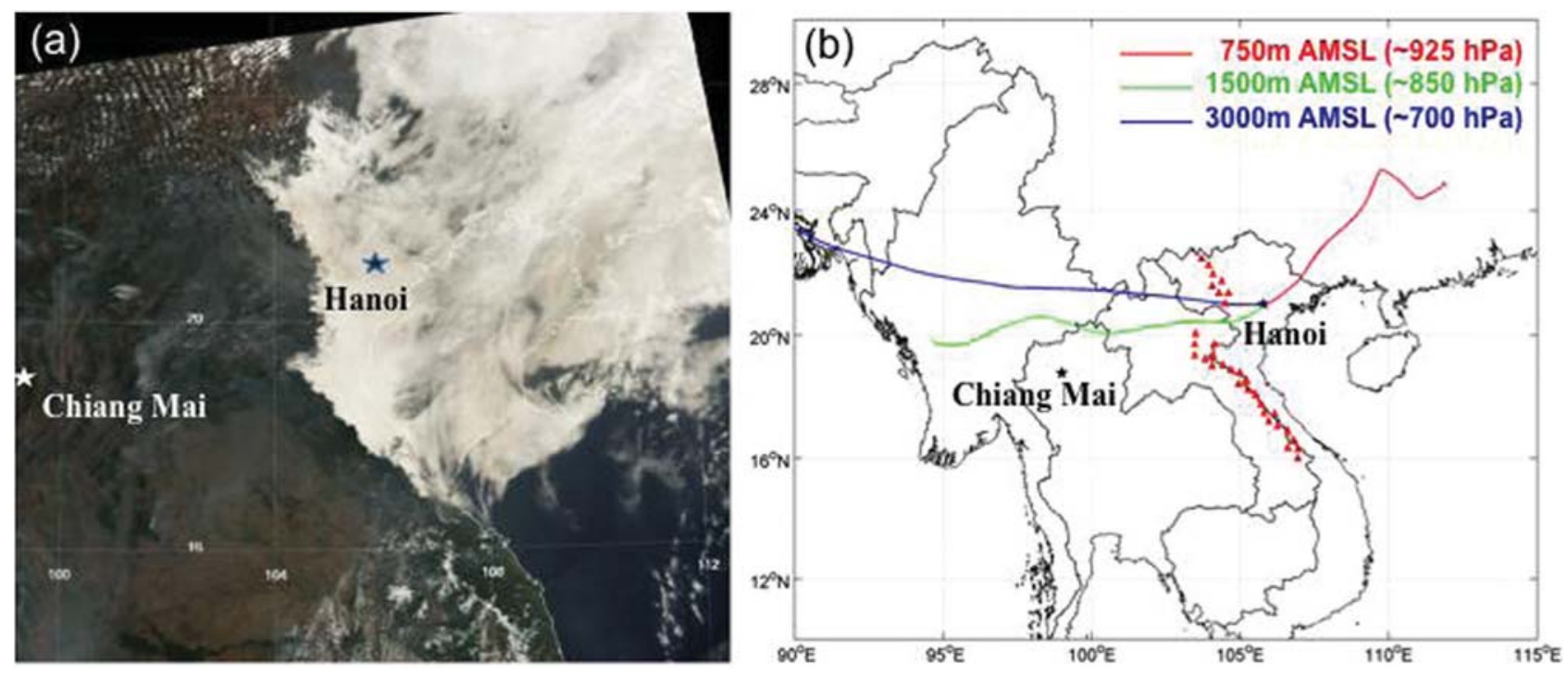

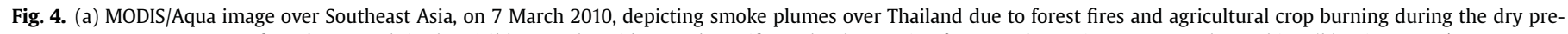

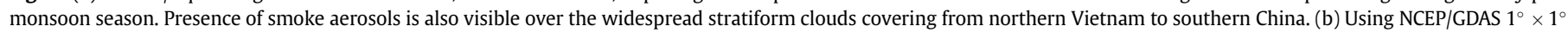

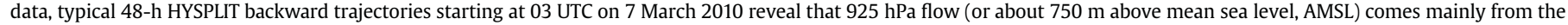

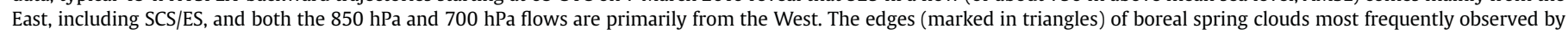
satellites are also superimposed on the map. 
well with the analyses of HYSPLIT backward trajectories (Draxler and Rolph, 2003), which indicate prevailing flow from the east at the $925 \mathrm{hPa}$ level. At higher altitudes ( 850 and $700 \mathrm{hPa}$ ), flow with transported aerosols is primarily from the west ( $c f$. trajectories in Fig. 4b).

Across Vietnam, a ground-based network of 231 meteorological stations, including 18 solar radiation posts, continuously monitor atmospheric conditions and surface irradiance. These surface observations were used to study the temporal distribution of clouds in this region. As shown in Fig. 5, the regional distributions of sunshine duration, measured by the surface solar irradiance transitioning through a prescribed threshold (e.g., mean value of $120 \mathrm{Wm}^{-2}$, as suggested by World Meteorological Organization, 2008), are highly variable across the seven climatic zones in Vietnam. Measurements of sunshine duration are linked to the methodology employed (e.g., pyranometric, pyroheliometric, etc.) and the seasonal and site dependencies in the surface irradiance at a given location. In a recent review paper, Wild (2009) reported that surface sunshine duration may serve as a useful proxy for surface solar radiation, in turn, indicating the frequency of occurrence of cloudiness. Annually, cloud-free conditions reported by meteorological stations exist about $22 \%$ of the time; hence, clouds are ubiquitous throughout the year with precipitating cloud systems contributing up to $1.5-2 \mathrm{~m}$ of rain over a period of about 100 days. The variability in total received surface solar irradiance (in terms of sunshine hours), and hence cloud cover, across the climatic zones, reflects the transition period between monsoon seasons during the year. Histograms depicting normalized frequency of sunlight hours reveal that the coastal regions in the northern (e.g., Hanoi) and central parts of the country exhibit minimum periods of sunlight corresponding to the southern monsoon (May-September). With the onset of northerly to northeasterly winds, the northern monsoon (October-April) leads to periods of greater sunlight hours in the country's southern regions (e.g., Ho Chi Minh City), whereas locations to the North are generally cloudy. Analyses of morning sounding profiles obtained during spring (February to May) 2005-2009 over Hanoi (east of the identified cloud-edge area in Fig. 4b) provide additional evidence that pre-monsoon clouds are predominantly located at 850-925 hPa, especially in February and March. More active cumulus convection in April and May drives up the overall cloud height over the region, while the cloud edge captured by satellite sensors becomes less evident. Compared to central Vietnam, northern Vietnam often lies on the transport pathways of biomass-burning aerosols originating from northern Myanmar/ Thailand/Laos. Thus, the best time for probing the aerosol-cloud interactions in northern Vietnam is from February to April. SMARTLabs-ACHIEVE, sporting a suite of cloud/rain radars and a passive microwave radiometer, will be instrumental in probing cloud microstructure and be strategically placed near the edge of cloud-dominated regions (e.g., Yen Bai, Vietnam in Fig. 2).

\subsection{Vertical distribution of aerosols and clouds and their interactions}

Prior to the onset of the Asian summer monsoon, smoke plumes and widespread stratiform clouds are often visible in satellite imagery (cf. Fig. 4a). Gautam et al. (2013) presented results from multi-year (2007-2011) analyses of space-borne CALIOP (CloudAerosol LIdar with Orthogonal Polarization) vertically-resolved measurements over Southeast Asia. In general, a strong northsouth gradient is observed from relatively clean equatorial environment to heavy smoke-laden northern regions. As shown in Fig. $6 a-b$, the boreal spring aerosols generally extend to altitudes of $\sim 4 \mathrm{~km}$ over northern Myanmar-Thailand-Laos and southern

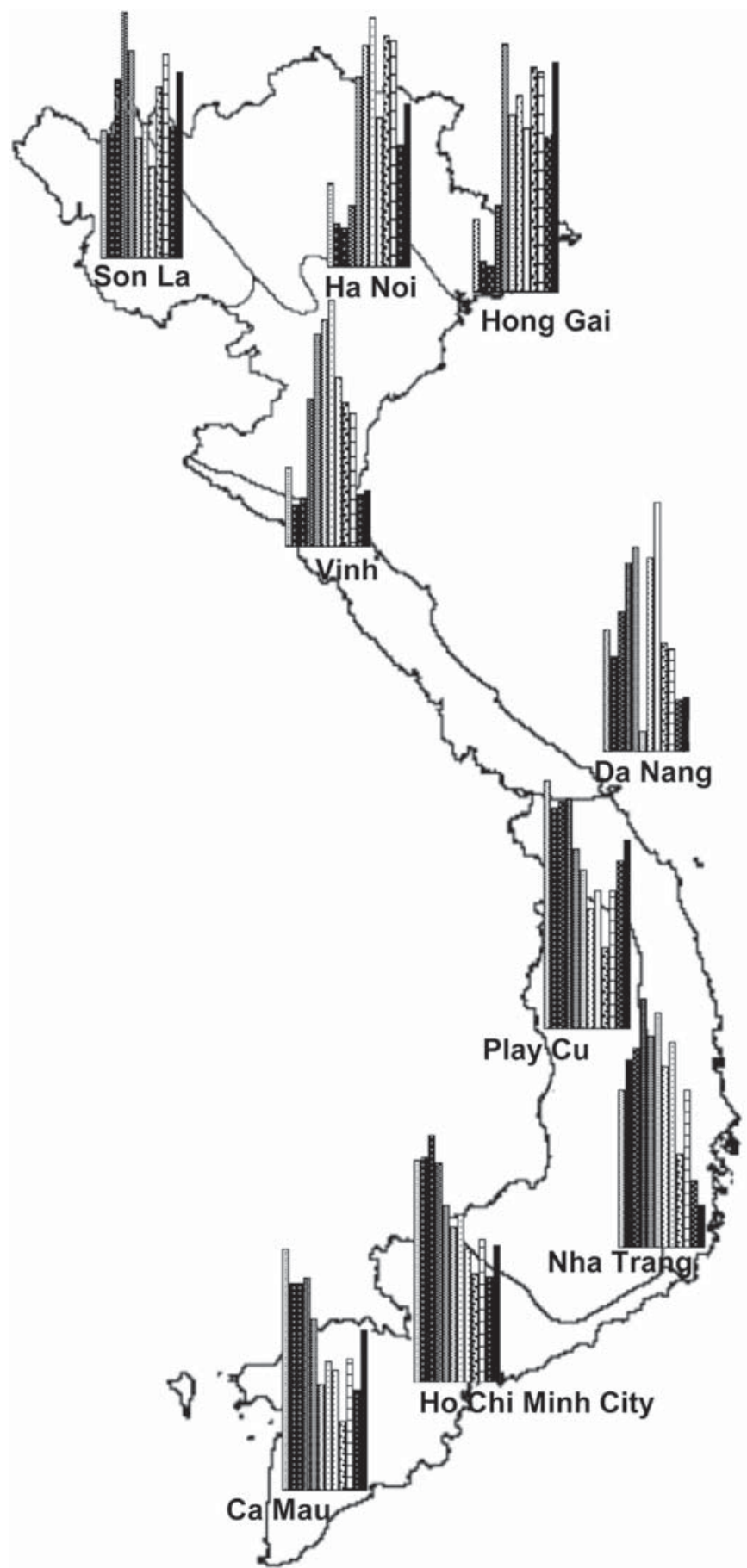

Fig. 5. Normalized frequency of occurrence in sunshine duration, based on measurements from 231 meteorological stations over seven climatic zones in Vietnam, used as a proxy of surface solar irradiance for depicting temporal distribution of cloud coverage. In boreal spring, the most prominent feature over northern Vietnam is frequently cloudy skies from mountain ranges to the East and cloud-free skies to the West.

China. The stratiform clouds are prevalent in the boundary layer with cloud tops at $\sim 2 \mathrm{~km}$ and depths of $\sim 1 \mathrm{~km}$ ( $c f$. the convergence of dew-point and air temperature in Fig. 6d). Smoke plumes from the region are frequently advected so as to overlying and overlapping with the cloud decks and cause cloud darkening (Hsu et al., 2003) by lowering the reflectivity/albedo at the top of atmosphere (TOA). As clearly seen in the CALIOP backscattered 

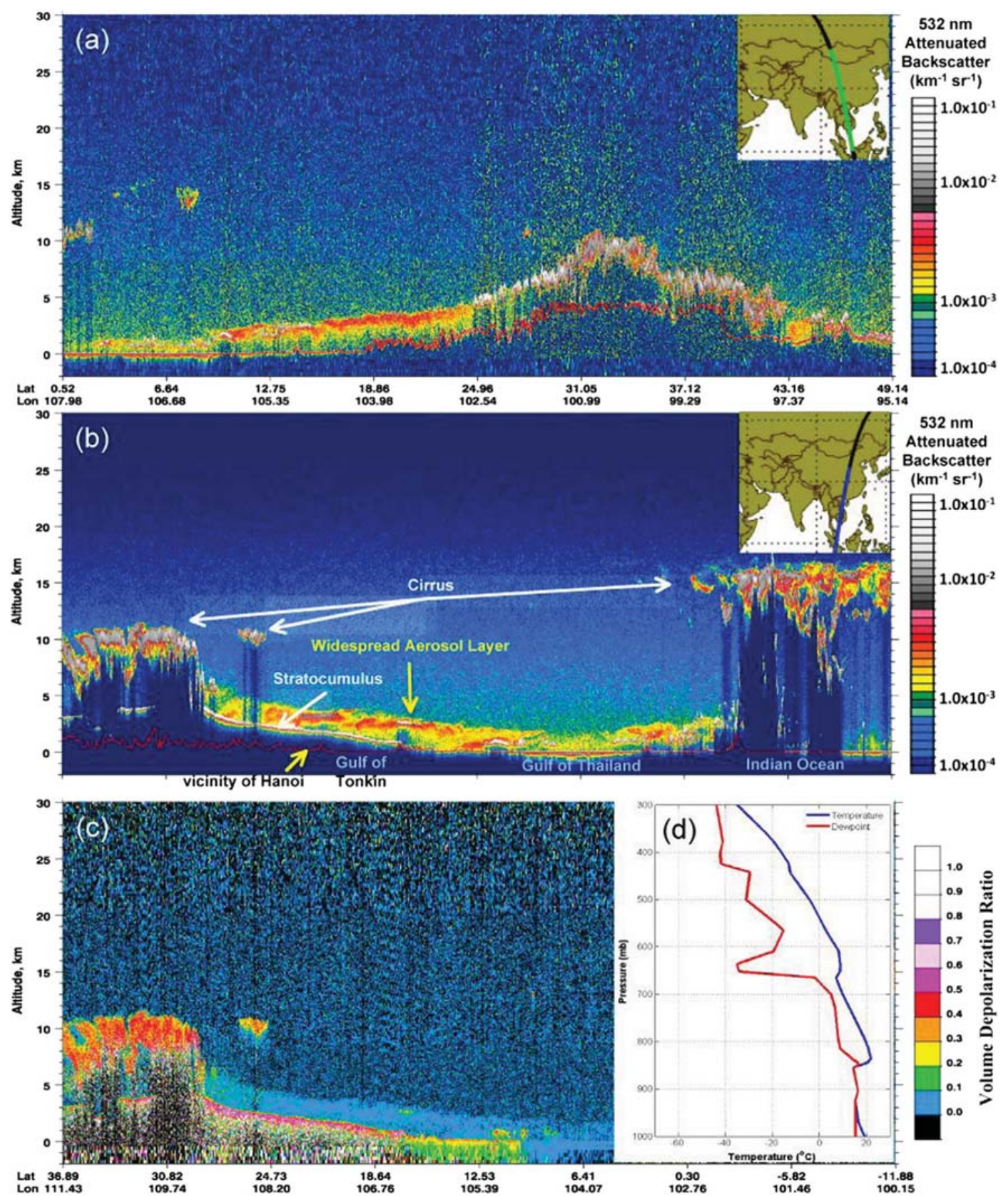

Fig. 6. On 7 March 2010, widespread aerosol layer across Southeast Asia measured by CALIOP shown (a) $532 \mathrm{~nm}$ attenuated backscatter in the daytime transect (inset) from MalayBorneo to northern China; (b) nighttime transect (inset) of $532 \mathrm{~nm}$ attenuated backscatter suggesting a prominent aerosol layer overlying and overlapping with the stratiform cloud deck from $\sim 16^{\circ} \mathrm{N}$ to $\sim 27^{\circ} \mathrm{N}$; (c) as in (b) but for corresponding CALIOP-derived volume depolarization ratio profile further indicating fine-mode aerosols above the cloud deck over Vietnam and southern China; and (d) radiosonde (12Z) profile of air temperature (blue) and dew-point (red) at Hanoi indicating presence of the shallow cloud deck approximately within 925-850 hPa, with an inversion layer above the cloud top.

signals, a smoke-laden aerosol layer resides in the vicinity of the cloud decks and appears to be directly placed on top of the stratiform layer (Fig. 6b). The close proximity of clouds to the overlying pronounced aerosol layer is also evident in the CALIOP-derived volume depolarization ratio (VDR, Fig. 6c) profile where the finemode aerosols are associated with VDR less than $10 \%$, in contrast to the higher VDR of the cloud decks. Based on these observations, it can be argued that aerosols and clouds in this region reflect the strength of a tightly coupled system and provide a unique test-bed for deepening the understanding of aerosol-cloud microphysical interactions as well as aerosol-induced radiative effects on regional cloudiness.

In addition to accurately detecting the vertical organization of cloud and aerosol layers by lidars, their spatial and temporal distributions obtained from imagers are also critical for quantifying the impacts of both aerosols and clouds on radiative energetics. Fig. 7 provides a global survey on the frequency of occurrence of absorbing aerosols in the presence of clouds, using the longest available satellite measurements by employing the Aerosol Index (AI; first introduced by Hsu et al., 1996) derived from the 


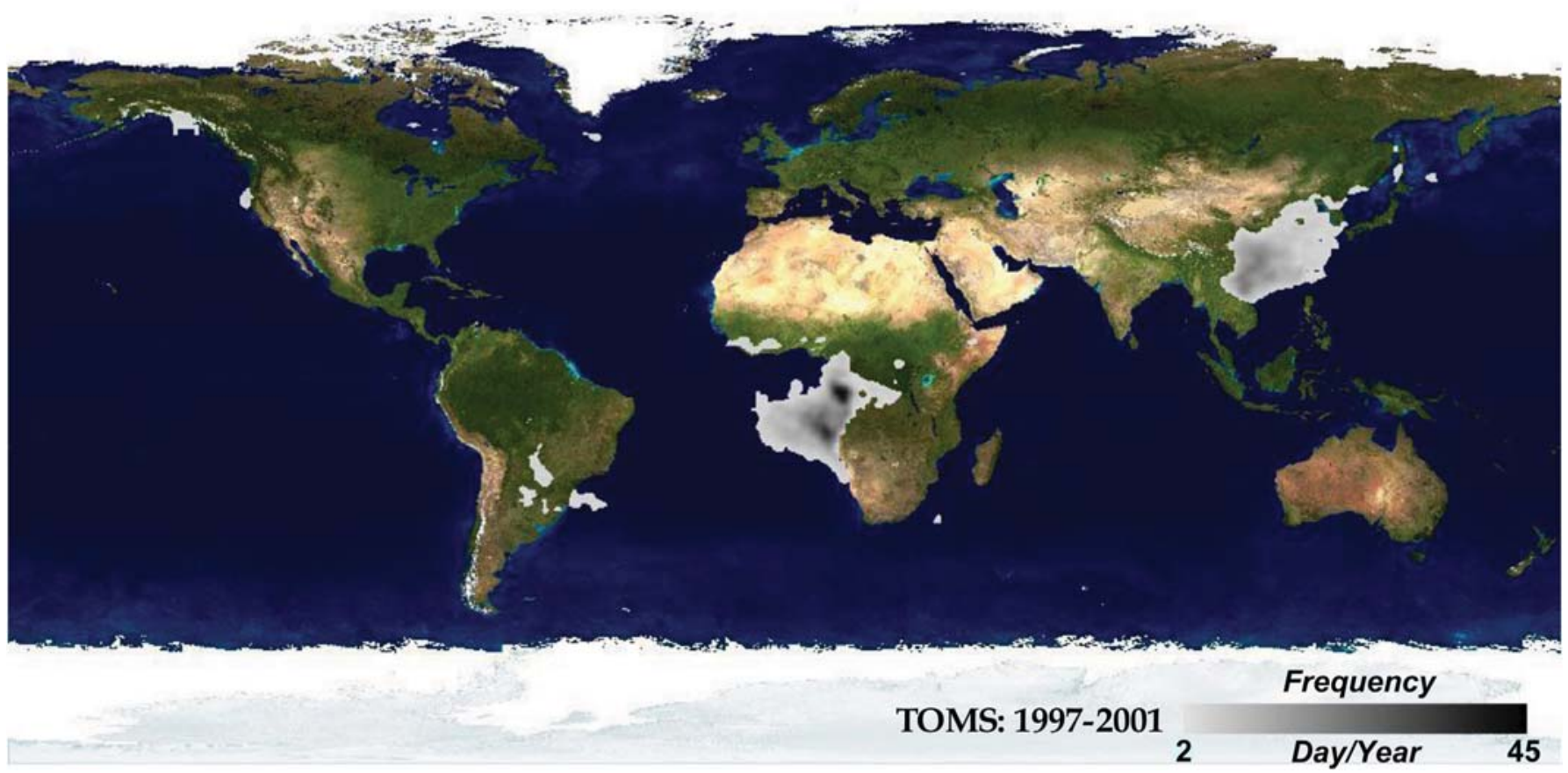

Fig. 7. Global frequency distribution (day year ${ }^{-1}$ ) of absorbing aerosols in the presence of clouds, defined as AI $>1.5$ (indicating moderate absorbing aerosol loading) and UV reflectivity > 35\% (specifying the presence of clouds) from TOMS daily Level-3 data between 1997 and 2001.

backscattered ultraviolet (UV) radiation by the Total Ozone Mapping Spectrometer (TOMS) aboard Earth Probe (in operation from 1996 to 2005). Note that since the Earth Probe TOMS sensor had degraded significantly after 2001, we only include the AI analysis using data acquired in 1997-2001. Similar patterns shown in Fig. 7 are also obtained, using measurements from either TOMS aboard Nimbus-7 (1978-1993) or the Ozone Monitoring Instrument (OMI) aboard Aura (2004 - present) acquired under nominal conditions without significant sensor calibration issues. The $\mathrm{AI}$ is a measure of the wavelength-dependent reduction of Rayleigh-scattered radiance by aerosol absorption relative to a pure Rayleigh atmosphere. However, the AI-AOT relationship depends on factors such as surface reflectance, aerosol height, aerosol type, and presence or absence of clouds. The resulting detections ( $c f$. Fig. 7) are clustered mainly in four regions in descending order of frequency of occurrence: southwestern Africa, northeastern Southeast Asia, Amazonia, and the west coast of North America. The environmental variations encountered in these regions offer different possibilities and challenges for studying aerosol-cloud interactions.

During boreal spring, Southeast Asia may provide a relatively simple, natural laboratory for investigating the interactions between absorbing aerosols in the presence of clouds, even though this region falls second in the frequency of occurrence. Absorbing aerosols produced by biomass burning in central and southern Africa have been the subject of field campaigns (e.g., Eck et al., 2001; Swap et al., 2003). Garstang et al. (1996) reported that in this region the frequent occurrence of a recirculation gyre, driven by interacting planetary- and synoptic-scale features of the general circulation in the southern hemisphere, can obfuscate the precise identification of aerosol sources and evolution of clouds/airmasses. The semi-permanent south Atlantic anticyclone, the continental anticyclone over southern Africa, and the south Indian anticyclone have a dominating effect on all transport patterns of aerosols and precursor gases including those produced by biomass-burning activities. Further complicating the study of aerosol-cloud interactions in this region is the recirculation (or stratified flows) occurring horizontally on a massive scale, and the absolutely stable capping layers strongly inhibit vertical transport (Garstang et al., 1996). This results in decoupled layers of aerosols and clouds that are often detected by satellite and aircraft measurements (e.g., Wilcox, 2012). Consequently, some degree of elevated uncertainties will be introduced when analyzing and interpreting the aerosolcloud interactions, which are intertwined with the kinematic and thermodynamic fields of motion and variables of state.

Over Amazonia, the interactions of biomass-burning aerosols with clouds can also be diverse. On the one hand, atmospheric heating due to aerosol absorption can suppress the formation of boundary-layer clouds (e.g., Koren et al., 2004). On the other, the aerosol particles can act as additional cloud condensation nuclei, suppressing precipitation at low altitudes, and result in the formation of pyro-cumulus clouds with elevated tops (e.g., Andreae et al., 2004). Amazonian smoke may also be entrained by deep convective clouds, and transported long distances at high altitudes (e.g., Edwards et al., 2006). Yu et al. (2007) found different links between aerosols and clouds in different years, probably attributed to changes in cloud vertical structure, although measurements were insufficient to draw strong conclusions. Additionally, the small size of many clouds in this region introduces 3-dimensional radiative transfer effects that hinder the interpretation of satellite data (e.g., Wen et al., 2007). Thus, these studies highlight the complexity of aerosol-cloud interactions in this region.

Off the west coast of North America, the compelling phenomena of aerosols interacting with clouds (marine boundary-layer-capped stratocumulus, covering about one-third of the ocean surface on Earth) are visible from tracks along the shipping lanes, observed by mariners as early as 1944 (Durkee et al., 2000). The formation and evolution of ship tracks can be viewed as a controlled experiment where anthropogenic pollution modulates the properties of an extensive cloud system (e.g., the albedo effect; Twomey et al., 1984), because ship tracks result from individual and localized sources (ship effluents) in a relatively simple marine environment within finite spatial and temporal scales. Recent studies (e.g., Christensen and Stephens, 2011) further illustrate that aerosols affect the microphysical (e.g., drop size) and macrophysical (e.g., water 
content) responses of marine stratocumulus to varying mesoscale cellular structures and ambient meteorological conditions above clouds. By analyzing a combination of satellite and reanalysis data, however, Peters et al. (2011) found no statistically significant effects of aerosols from ship emissions on large-scale cloud fields over remote oceans. Similarly, smoke aerosols produced by occasional biomass-burning events in Canada and Russia can be transported long distances, with noticeable effects on the meteorology and radiation budget of the affected regions (e.g., Hsu et al., 1999; Jaffe et al., 2004). However, the spatial and inter-annual variability are so large as to preclude these events for planning a field campaign designed to probe aerosol-cloud interactions.

Biomass-burning aerosols above clouds can potentially enhance absorption of solar radiation and the associated radiative warming may lead to subsequent feedbacks on the regional cloudiness. Using a satellite-based approach, Chand et al. (2009) showed that the radiative warming of smoke aerosols increases with underlying cloud coverage leading to a positive aerosol radiative effect at the TOA over the southeast Atlantic. Model simulations (Perlwitz and Miller, 2010) suggested analogous results due to absorbing dust (or black carbon) aerosols. In addition, Wilcox (2012) showed that observed enhancement in the cloud liquid water path suggests thickening of the stratocumulus cloud decks over the southeast Atlantic, during episodes of smoke-above-clouds, leading to aerosol-induced radiative cooling. The increases of cloud water content were attributed to an additional mechanism whereby radiative warming of the elevated smoke layer enhances the buoyancy of the free tropospheric air above clouds and inhibits cloud-top entrainment. Similarly, over northern regions of Southeast Asia, for stratiform cloud decks beneath smoke layers, enhanced aerosol solar absorption may reduce relative humidity thus promoting evaporation of clouds (via so-called semi-direct aerosol effects). The competing cooling effect induced by absorbing aerosols over the southeast Atlantic, shown to partially compensate for the positive warming effect, may therefore take place over this region as well. However, as observed by CALIOP backscatter data, the smoke layer resides in close proximity to the top of the stratiform cloud decks over northern regions of Southeast Asia and a free tropospheric pristine layer, separating the aerosols from clouds, may be absent. By comparison, over the southeast Atlantic, the smoke and cloud layers were found to be separated by at least $250 \mathrm{~m}$ in the vertical domain (e.g., Chand et al., 2009; Wilcox, 2012). Therefore, it remains for future investigations to demonstrate how a relatively closed smoke-above-cloud environment, as observed over northern Southeast Asia, may influence the overall changes in radiative effect compared to a decoupled smoke-abovecloud scenario over the southeast Atlantic.

Furthermore, during the 7-SEAS springtime 2010 experiment conducted at Dongsha Island in the northern SCS/ES, ground-based EZ-lidar NRB measurements along with aerosol chemical analyses show compelling evidence for an aerosol-rich environment with noticeable vertical structure (Wang et al., 2013; Atwood et al., 2013). Combining these measurements with aerosol transport models provides additional insight into the origins of the air masses. The measurements corroborate the linkage of vertically stratified and temporally inhomogeneous aerosol layers over the SCS/ES with strong vertical wind shear and temperature inversion, leading to a complex structure of distinct aerosol types. This vertical distribution has important implications for remote sensing applications and also its effects on the energy balance of the atmosphere. Perturbations to the monsoon onset conditions over Southeast Asia during springtime can potentially have great influence on the development of the large-scale Asian summer monsoon (Lau and Yang, 1997). Therefore, multi-sensor satellite (imager, lidar and radar) as well as surface-based observations are required to simultaneously characterize the coupled aerosol-cloud structure and their physical properties, which will help improve microphysical and radiative parameterizations of aerosol-cloud interactions. A synergy of ground-based, space-borne and suborbital measurements, along with cloud resolving models, is required to further establish the vertical structure of the aerosol-cloud interaction zone over Southeast Asia and to better understand the associated radiative-convective feedbacks.

\subsection{Regional aerosol radiative effects and impact assessment}

Southeast Asia witnesses the earliest spells of rainfall thus marking the onset of the Asian summer monsoon. The premonsoon season represents a transition period from dry stable atmospheric conditions (February-March) to enhanced convective activities and the onset of the rainy season (late April-early May) in Southeast Asia. During the dry pre-monsoon period, extensive biomass burning contributes significantly to the regional aerosol emissions. As already discussed, the smoke plumes are observed to advect over large areas of stratiform clouds, leading to enhanced perturbation of radiative energetics by the aerosol-cloud system. By combining narrowband radiance (SeaWiFS and TOMS) with broadband irradiance (CERES) measurements, Hsu et al. (2003) reported that instantaneous reflected solar (emitted thermal) radiation from clouds at the TOA due to smoke aerosols can be reduced (enhanced) by as much as 100 (20) $\mathrm{Wm}^{-2}$ during March 2000. Thus, the modulation of cloud radiative forcing by smoke aerosols during the pre-monsoon season may play a significant role in perturbing the summer monsoon circulation and rainfall patterns, as also demonstrated by climate modeling (e.g., Ramanathan et al., 2005).

Gautam et al. (2013) further studied the optical and radiative properties of aerosols over Southeast Asia during pre-monsoon season from satellite and ground-based radiometric measurements. Based on column-integrated, surface measurements from four AERONET locations distributed over Thailand (Chiang Mai, Mukdahan, Phimai and Silpakorn University), the regional aerosol loading was found to be significantly absorbing, characterized by the spectral single-scattering albedo, $\omega$, below $0.91 \pm 0.03$ in the 440-670 nm range. During February-April in 2008-2009, the lowest seasonal-mean $\omega$ (most absorbing aerosols) was found over Chiang Mai $(\omega \sim 0.85 \pm 0.03$ ), associated with heavy biomassburning aerosols and local urban pollution. Using instantaneous CERES TOA shortwave irradiance in conjunction with MODIS AOT $(\tau)$ over AERONET sites, the aerosol radiative forcing efficiency, $F_{\mathrm{E}}$, can be determined under cloud-free conditions. The instantaneous $F_{\mathrm{E}}$ at the TOA varied from $18.6 \pm 0.96 \mathrm{Wm}^{-2} \tau^{-1}$ at Chiang Mai to $30 \pm 2.91 \mathrm{Wm}^{-2} \tau^{-1}$ at Phimai. Overall, consistency in the aerosol radiative impact was found between the AERONET-retrieved $\omega$ and satellite-derived $F_{\mathrm{E}}$ at the TOA - the lower $\omega$, the smaller $F_{\mathrm{E}}$. Although regional aerosols are significantly absorbing compared to those reported by Patadia et al. (2008) over Amazonia (based on satellite-derived $F_{\mathrm{E}}$ ), especially over Chiang Mai, the analyses of $F_{\mathrm{E}}$ indicate that the aerosol layer is more reflecting than the underlying surface, as it is associated with a positive $F_{\mathrm{E}}$, i.e., increasing TOA reflected irradiance with respect to increases of AOT and therefore induce negative forcing at the TOA.

In addition to evaluating aerosol climatic effects, regional modeling studies (Fu et al., 2012; Huang et al., 2013) were conducted to assess the impact of biomass burning on atmospheric composition in Southeast Asia by using CMAQ (Community Multiscale Air Quality modeling system; Byun and Schere, 2006). Measurements (e.g., CO, a common tracer for biomass-burning sources) from BASE-ASIA at Phimai were first compared to the simulations using two biomass-burning emission inventories: 
FLAMBE (Fire Locating and Modeling of Burning Emissions; Reid et al., 2009) and GFED. The comparison indicated that the FLAMBE emission inventory performed better in this region than GFED, due to additional emissions contributed from fires by agricultural wastes. In the source region (Southeast Asia), biomass burning could contribute as high as $400 \mathrm{ppbv}, 20 \mathrm{ppbv}$ and $80 \mu \mathrm{g} \mathrm{m}^{-3}$ to the surface $\mathrm{CO}, \mathrm{O}_{3}$ and $\mathrm{PM}_{2.5}$ concentrations, respectively. Upward transport from the surface to high altitudes was simulated, along with a strong eastward transport between $2 \mathrm{~km}$ and $8 \mathrm{~km}$. Concentrations due to long-range transport could also range from about 160 to $360 \mathrm{ppbv}, 8$ to $18 \mathrm{ppbv}$ and 8 to $64 \mu \mathrm{g} \mathrm{m}{ }^{-3}$ for $\mathrm{CO}, \mathrm{O}_{3}$ and $\mathrm{PM}_{2.5}$ in the downwind regions, respectively. Although discrepancies existed between CMAQ simulations and measurements from both satellite and surface networks due to high uncertainties in emission inventories, chemical tracers of particulate $\mathrm{K}^{+}, \mathrm{OC}$ concentrations and $\mathrm{OC} / \mathrm{EC}$ ratios showed distinct regional characteristics, suggesting biomass burning and local anthropogenic emissions dominated the aerosol chemical composition and AOT. Scenario simulations indicated that the impact of biomass burning on the downwind regions spread over a large area via the Asian spring monsoon, which included southern China, SCS/ES, and Taiwan Strait. In the source regions, the contribution from biomass burning to AOT was estimated to exceed $56 \%$, while in the downwind regions, the contribution was still noteworthy within the range of $26 \%-62 \%$. These studies clearly show the significant impact of biomass-burning aerosols on the air quality in both local and downwind areas over Southeast Asia, particularly during biomass-burning episodes.

Furthermore, transpacific transport and the impact of Asian dust aerosols have been well documented, but little is known about their invasion to the SCS/ES during boreal spring. Wang et al. (2011) presented the first detailed characterization of such case during 7-SEAS/ Dongsha. On 19-21 March 2010, a fierce Asian dust storm affected large areas from the great Gobi Deserts to the West Pacific, including Taiwan and Hong Kong. Utilizing SMARTLabs-COMMIT in-situ measurements and lidar profiling, the concentration, size distribution, hygroscopicity, optical properties and vertical structures of this longrange transport dust event were analyzed. The dust particles were mixed with anthropogenic and marine aerosols, and transported near the surface. These results lead to an important implication regarding the extent to which the Asian dust transport may influence biogeochemistry in northern SCS/ES. This region represents a unique biogeochemical environment in the world's marginal seas, characterized by iron-depleted and oligotrophic surface waters. For years, it was widely believed that this region received significant amount of dust aerosols from the Asian continent. Hence, many regional oceanic studies have proposed that atmospheric forcing plays a major role in the marine ecosystem, even though the observational evidence is sparse. Wang et al. (2012) presented a satellite perspective on Asian dust-triggered biogeochemical response over the northern SCS/ES, in which long-term satellite data and 16-year surface $\mathrm{PM}_{10}$ observations were integrated to provide strong evidence for the dust transport and significant enhancement of chlorophyll blooms. Dust-laden air masses in six historical heavy-dust events were shown to contain readily bio-available iron for immediate uptake by phytoplankton to cause successive blooming.

Besides atmospheric composition, another fundamental quantity, the redistribution of fresh water, which includes severe drought and flooding, can be affected by anthropogenic emissions - an outstanding issue relevant to global community. To study the large-scale aerosol-cloud-precipitation interactions, a synergy of long-term multi-sensor (passive and active) observations and model simulations is required. High aerosol anomalies are often associated with overall reduced precipitation and fewer raining days but enhanced rain intensity, reduced mid-tropospheric latent heating, and a redistribution of columnar radiative energetics in the region. Three main factors mediate large-scale covariability between aerosol and precipitation. The first is the washout effect, whereby precipitation leads to wet deposition of aerosol particles, and is negative because stronger or longer duration rain removes more aerosols from the atmosphere. The second component is aerosol direct (e.g., Ramanathan et al., 2001), semi-direct (e.g., Ackerman et al., 2000; Feingold et al., 2001), and indirect (e.g., Twomey et al., 1984; Albrecht, 1989) radiative effects on precipitation, which can be of either sign. The third factor in the aerosolprecipitation covariability is mediated by large-scale climate systems such as ENSO and by diurnal time-scale meteorological variables such as water vapor (e.g., Prospero and Lamb, 2003).

Satellite measurements (e.g., rainfall rate of TRMM/3B43 product, Huffman et al., 2007; AOT from SeaWiFS, Hsu et al., 2012; Sayer et al., 2012a,b) provide an effective means for examining aerosolprecipitation covariability. SeaWiFS presently provides the longest single-sensor satellite AOT dataset, and the record (19972010) predates that of the other EOS-era sensors. Examples of aerosol-precipitation covariability are shown in Fig. 8 , at $0.5^{\circ}$
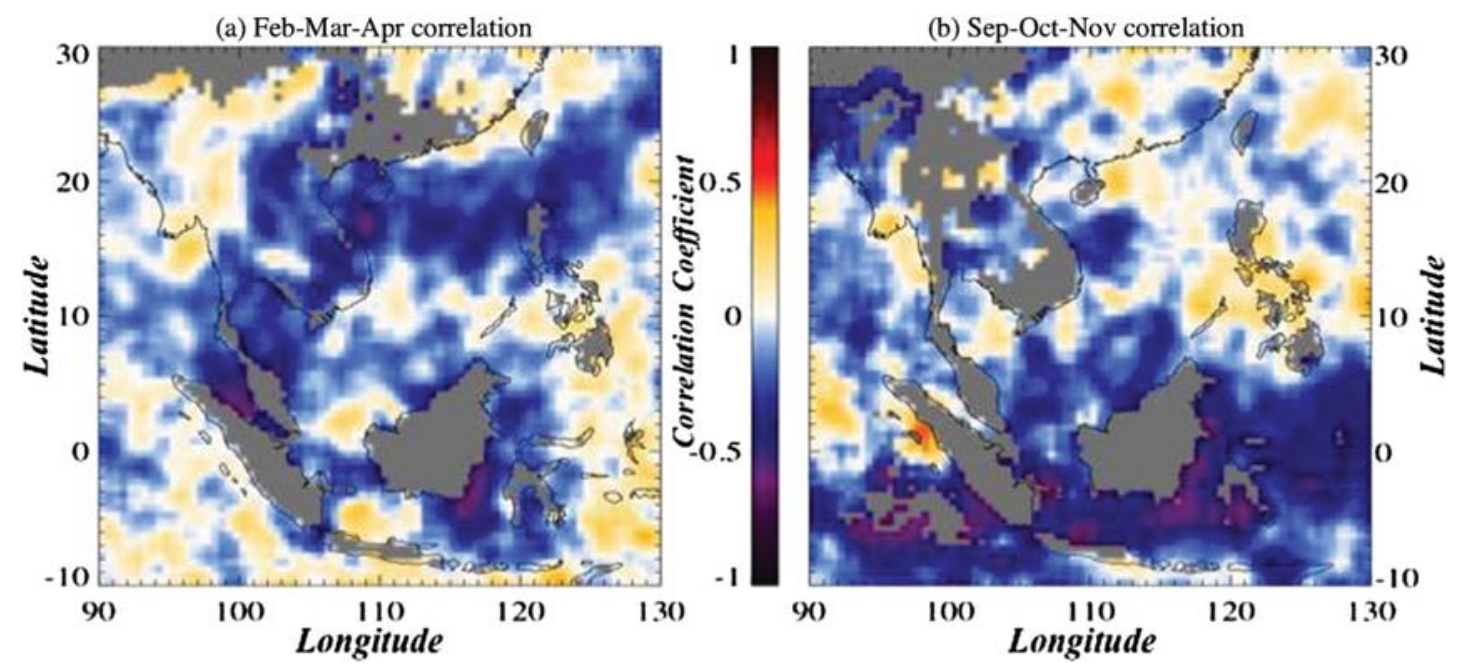

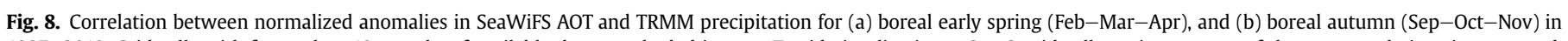

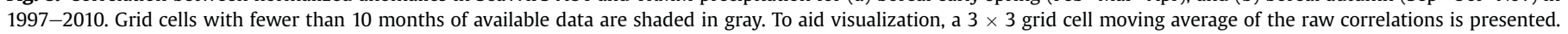


resolution, presented as the correlation coefficient between normalized AOT and precipitation anomalies in each grid cell. Seasonal cycles were removed to keep the primary focus on the anomalies from the climatology of these parameters. Then, normalization was performed by dividing the residual anomalies by the corresponding seasonal cycle of standard deviation calculated from the raw data. Monthly data were used because aerosol events in this region often occur at synoptic scales, and therefore aggregation from daily to monthly minimizes the impact of washout effect and cloud cover on spatial completeness. In Fig. 8, two seasons are presented: (a) early boreal spring (Feb-Mar-Apr), when biomass burning is active in the northern part of the region, and smoke aerosols are transported above low-level stratiform clouds over the SCS/ES, and (b) boreal autumn (Sep-Oct-Nov), when AOT tends to peak in the southern part of the region. The correlation shows a clear regional and seasonal dependence, with widespread anti-correlation over the northern SCS/ES in (a) and over the equatorial region in (b). Untangling the contributions of the three aforementioned factors (washout, aerosol radiative effects, climate/meteorological factors) to the observed covariability is a complicated task (e.g., Stevens and Feingold, 2009). White areas in Fig. 8 indicate those grids with fewer than 10 data points, mostly due to missing SeaWiFS AOT monthly-mean values because of persistent high cloud coverage, showing that satellite data alone cannot provide the complete picture. Determination of columnar aerosol loading in the presence of clouds from satellite passive sensors is extremely difficult, while ground-based measurements of aerosol deposition are still very limited and sparse. These underscore the need for further studies to improve our understanding of aerosol-cloud-precipitation interactions, allowing the eventual attribution of the causes for the observed relationships, which remains an open-ended question at the present time.

\section{Concluding remarks and future work}

This overview paper presents an integrative summary of related papers in this special issue. It advances the first wave of analyses of aerosol and cloud properties using BASE-ASIA and 7-SEAS IOPs' measurements and serves as an anchor point for future studies and deployments in the northern regions of Southeast Asia for better understanding of the aerosol-cloud interactions. The major research objectives of BASE-ASIA and 7-SEAS/Dongsha/Son La experiments are to characterize the microphysical, chemical, optical and radiative properties of boreal spring biomass-burning aerosols near the source/downwind regions and along the transport pathways. Synergizing satellite observations, sophisticated platforms (e.g., SMARTLabs) and unique ground-based networks (e.g., AERONET/MPLNET) measurements, along with regional atmospheric transport and chemical models will further advance our present knowledge and enhance the critically needed database for biomass-burning aerosols.

Under the influence of increased aerosol loading, observational and modeling studies have shown precipitation suppression or enhancement for clouds dominated by warm rain processes ( $c f$. Stevens and Feingold, 2009 for a review and references therein). The ability of aerosols to affect cloud development and precipitation processes is highly dependent on the state of the atmosphere: its stability, humidity, composition of soluble gas species present that facilitate droplet nucleation in addition to the ambient aerosol types (e.g., solubility). In general, clouds in polluted air masses tend to consist of smaller droplet sizes and result in narrower droplet size spectra. Hydrometeor distributions dominated by smaller sizes also tend to increase cloud albedo and cloud amount, as well as reduce the amount of precipitation. Precipitation reduction is primarily due to reduced collision efficiencies of the smaller cloud droplets that develop under higher aerosol concentrations. SMARTLabs' capabilities of measuring local thermodynamic parameters and aerosol properties coupled with the newly acquired multi-frequency radars and multi-wavelength lidars will be employed in the spring 2013 7-SEAS campaign to explore various mechanisms involved in aerosol-cloud interactions alluded in the preceding discussion. Additionally, detailed and quantitative measurements of environmental variables needed to refine the modeling of aerosol-cloud interactions in warm rain processes will be provided.

The frequency-dependent radar reflectivity, as well as its associated polarimetric and Doppler signatures, is the response to a characteristic volume of hydrometeors with intrinsic properties such as size, shape, density, water content, and orientation (e.g., Bringi and Chandrasekar, 2001). The ability to model aerosol-cloud interactions for a spectrum of cloud types, ranging from large-scale stratiform to localized deep convective clouds, requires a microphysical scheme capable of representing the range of hydrometeor types and variations in the hydrometeor distributions developing within these clouds. Microphysical schemes in advanced cloud ensemble models (e.g., Cotton et al., 2003; Tao et al., 2003) can readily be modified to better account for variations in the hydrometeor distributions by the prediction of a third moment (spectral width parameter) in addition to the two moments (number and mass concentrations), which will lead to improved accuracy in the representation of time-dependent hydrometeor size distributions (e.g., Milbrandt and Yau, 2005; Loftus, 2012). This novel approach allows the hydrometeor size distributions to vary freely under changing meteorological conditions, such as the seasonal transition from stratiform to deep convection over the northern regions in 7SEAS. In turn, three-moment bulk microphysical schemes will result in improved simulation of microphysical processes and allow for more accurate calculations of radar reflectivity (e.g., Dawson et al., 2010; Loftus, 2012), which can then be used to gauge model performance against both ground-based and satellite observations as well as to provide insight into various physical processes.

Measurements from different space-borne sensors (MODIS, CALIOP, CloudSat, etc.) are taken at different spatial/temporal resolutions. This introduces difficulties in exploiting the synergy in the measurements to investigate aerosol-cloud interactions or using the data directly in retrievals of cloud microphysical properties due to the resolution dependence. Surface-based observations do not exhibit this problem to the same extent because the meteorological targets are much closer to the active probes such as lidar and radar, making the field-of-view of these instruments more commensurate. It is also noted that aerosols in particular tend to be frequently distributed spatially at lower altitudes. Furthermore, the observation time from the surface is much longer than from space, enabling a more detailed understanding of the life cycle of meteorological processes, not otherwise possible from space-borne platforms. Hence spectral/temporal issues associated with spatial sampling are greatly mitigated (e.g., Stevens and Feingold, 2009). All of the above point to a vision of the future, where surface observations (at the regional scale) complement satellite observations at the global scale. With aid from new microphysical schemes, advanced cloud ensemble models offer a quantitative means to connect satellite observations with ground-based measurements, furthering the understanding aerosol-cloud interactions.

\section{Acknowledgment}

The lead author thanks the continuous support of SMARTLabs deployments in Southeast Asia, as part of NASA Radiation Sciences Program managed by Dr. Hal B. Maring. Deployment of 7-SEAS/Son 
La IOP and data analysis are funded by NASA Interdisciplinary Studies (IDS) project, "Effects of biomass burning on Asian Monsoon water cycle and climate." We thank the NASA/EOS science teams of TOMS/OMI/SeaWiFS/MODIS/CALIPSO and AERONET/MPLNET for providing satellite and network data, respectively. The authors also gratefully acknowledge the team efforts led by J. Boonjawat (Southeast Asia START Regional Center at Chulalongkorn University, Thailand) and K. Bhuranapanon (Head of Phimai observatory and radar station, Bureau of Royal Rainmaking and Agricultural Aviation, Thailand) for supporting BASE-ASIA deployment, and by Anh X. Nguyen (Institute of Geophysics at Vietnam Academy of Science and Technology, Vietnam), S. Janjai (Department of Physics at Silpakorn University, Thailand), and N.-H. Lin (Department of Atmospheric Sciences at National Central University, Taiwan) in supporting 7-SEAS IOPs (2010-2012) over northern Southeast Asia.

\section{Appendix A. Supplementary data}

Supplementary data related to this article can be found at http:// dx.doi.org/10.1016/j.atmosenv.2012.12.013.

\section{References}

Ackerman, A.S., Toon, O.B., Stevens, D.E., Heymsfield, A.J., Ramanathan, V., Welton, E.J., 2000. Reduction of tropical cloudiness by soot. Science 288 (5), 1042-1047.

Adler, R.F., Huffman, G.J., Chang, A., Ferraro, R., Xie, P., Janowiak, J., Rudolf, B., Schneider, U., Curtis, S., Bolvin, D., Gruber, A., Susskind, J., Arkin, P., 2003. The version 2 Global Precipitation Climatology Project (GPCP) monthly precipitation analysis (1979-present). Journal of Hydrometeorology 4, 1147-1167.

Akagi, S.K., Yokelson, R.J., Wiedinmyer, C., Alvarado, M.J., Reid, J.S., Karl, T., Crounse, J.D., Wennberg, P.O., 2011. Emission factors for open and domestic biomass burning for use in atmospheric models. Atmospheric Chemistry and Physics 11, 4039-4072.

Albrecht, B., 1989. Aerosols, cloud microphysics, and fractional cloudiness. Science $245,1227-1230$.

Anderson, T.L., Covert, D.S., Wheeler, J.D., Harris, J.M., Perry, K.D., Trost, B.E., Jaffe, D.J., Ogren, J.A., 1999. Aerosol backscatter fraction and single scattering albedo: measured values and uncertainties at a coastal station in the Pacific Northwest. Journal of Geophysical Research - Atmospheres 104 (D21), 26,79326,807. http://dx.doi.org/10.1029/1999JD900172.

Andreae, M.O., Rosenfeld, D., Artaxo, P., Costa, A.A., Frank, G.P., Longo, K.M., SilvaDias, M.A.F., 2004. Smoking rain clouds over the Amazon. Science 303 (5662), 1,337-1,342. http://dx.doi.org/10.1126/science.1092779.

Andreae, M.O., Jones, C.D., Cox, P.M., 2005. Strong present-day aerosol cooling implies a hot future. Nature 435, 1187-1190.

Atwood, S.A., Reid, J.S., Kreidenweis, S.M., Cliff, S., Zhao, Y., Lin, N.-H., Tsay, S.-C., Chu, Y.-C., Westphal, D.L., 2013. Size resolved measurements of springtime aerosol particles over the northern South China Sea. Atmospheric Environment 78, 134-143.

Bell, S.W., Hansell, R.A., Chow, J.C., Tsay, S.-C., Wang, S.-H., Ji, Q., Li, C., Watson, J.G., Khylstov, A., 2013. Constraining aerosol optical models using ground-based, collocated particle size and mass measurements in variable air mass regimes during the 7-SEAS/Dongsha experiment. Atmospheric Environment 78, 163173.

Bringi, V.N., Chandrasekar, V., 2001. Polarimetric Doppler Weather Radar: Principles and Applications. Cambridge University Press. ISBN13: 978-0521019552.

Byun, D., Schere, K.L., 2006. Review of the governing equations, computational algorithms, and other components of the models-3 Community Multiscale Air Quality (CMAQ) modeling system. Applied Mechanics Reviews 59, 51-77.

Chand, D., Wood, R., Anderson, T.L., Satheesh, S.K., Charlson, R.J., 2009. Satellitederived direct radiative effect of aerosols dependent on cloud cover. Nature Geoscience 2 (3), 181-184. http://dx.doi.org/10.1038/ngeo437.

Chang, D., Song, Y., 2010. Estimates of biomass burning emissions in tropical Asia based on satellite-derived data. Atmospheric Chemistry and Physics 10, 23352351.

Christensen, M.W., Stephens, G.L., 2011. Microphysical and macrophysical responses of marine stratocumulus polluted by underlying ships: evidence of cloud deepening. Journal of Geophysical Research - Atmospheres 116, D03201. http:// dx.doi.org/10.1029/2010JD014638.

Chuang, M.-T., Lin, N.-H., Chang, S.-C., Wang, J.-L., Sheu, G.-R., Chang, Y.-J., Lee, C.-T., 2013. Aerosol chemical properties and related pollutants measured at Dongsha Island in the northern South China Sea during 7-SEAS/Dongsha experiment. Atmospheric Environment 78, 82-92. http://dx.doi.org/10.1016/j.atmosenv.2012.05.014.

Cotton, W.R., Pielke Sr., R.A., Walko, R.L., Liston, G.E., Tremback, C.J., Jiang, H., McAnnelly, R.L., Harrington, J.Y., Nicholls, M.E., Carrio, G.G., McFadden, J.P., 2003. RAMS 2001: current status and future directions. Meteorological and Atmospheric Physics 82, 5-29.
Crutzen, P.J., Andreae, M.O., 1990. Biomass burning in the tropics: impact on atmospheric chemistry and biogeochemical cycles. Science 250, 1669-1678.

Dawson II, D.T., Xue, M., Milbrandt, J.A., Yau, M.K., 2010. Comparison of evaporation and cold pool development between single-moment and multimoment bulk microphysics schemes in idealized simulations of tornadic thunderstorms. Monthly Weather Review 138, 1152-1171.

Draxler, R.R., Rolph, G., 2003. HYSPLIT4 (HYbrid Single-particle Lagrangian Integrated Trajectory) Model. Air Resour. Lab., Natl. Oceanic and Atmos. Admin. Silver Spring, MD. Available at: http://www.arl.noaa.gov/ready/hysplit4.html.

Durkee, P.A., Noone, K.J., Bluth, R.T., 2000. The Monterey area ship track experiment Journal of Atmospheric Science 57, 2523-2541.

Eck, T.F., Holben, B.N., Ward, D.E., Dubovik, O., Reid, J.S., Smirnov, A., Mukelabai, M.M., Hsu, N.C., O'Neill, N.T., Slutsker, I., 2001. Characterization of the optical properties of biomass burning aerosols in Zambia during the 1997 ZIBBEE field campaign. Journal of Geophysphysical Research - Atmospheres 106, 3425-3448. http://dx.doi.org/10.1029/2000JD900555.

Edwards, D.P., Emmons, L.K., Gille, J.C., Chu, A., Attie, J.-L., Giglio, L., Wood, S.W., Haywood, J., Deeter, M.N., Massie, S.T., Ziskin, D.C., Drummond, J.R., 2006. Satellite-observed pollution from Southern Hemisphere biomass burning. Journal of Geophysical Research - Atmospheres 111, D14312. http://dx.doi.org/10.1029/ 2005JD006655.

Feingold, G., Remer, L.A., Ramaprasad, J., Kaufman, Y.J., 2001. Analysis of smoke impact on clouds in Brazilian biomass burning regions: an extension of Twomey's approach. Journal of Geophysical Research - Atmospheres 106 (D19), 22907-22922.

Fu, J.S., Hsu, N.C., Gao, Y., Huang, K., Li, C., Lin, N.-H., Tsay, S.-C., 2012. Evaluating the influences of biomass burning during 2006 BASE-ASIA: a regional chemica transport modeling. Atmospheric Chemistry and Physics. http://dx.doi.org/ 10.5194/acp-12-1-2012.

Garstang, M., Tyson, P.D., Swap, R.J., Edwards, M.T., Kållberg, P., Lindesay, J.A., 1996. Horizontal and vertical transport of air over southern Africa. Journal of Geophysical Research 101 (D19), 23,721-23,736. http://dx.doi.org/10.1029/ 95JD00844.

Gautam, R., Hsu, N.C., Eck, T.F., Holben, B.N., Janjai, S., Jantarach, T., Tsay, S.-C., Lau, K.-M., 2013. Characterization of aerosols over the Indochina peninsula from satellite-surface observations during biomass burning pre-monsoon season. Atmospheric Environment 78, 51-59.

Giglio, L., Csiszar, I., Justice, C.O., 2006. Global distribution and seasonality of active fires as observed with the Terra and Aqua Moderate Resolution Imaging Spectroradiometer (MODIS) sensors. Journal of Geophysical Research - Atmospheres 111, G02016. http://dx.doi.org/10.1029/2005JG000142.

Holben, B.N., Eck, T.F., Slutsker, I., Tanré, D., Buis, J.P., Setzer, A., Vermote, E., Reagan, J.A., Kaufman, Y.J., Nakajima, T., Lavenu, F., Jankowiak, I., Smirnov, A. 1998. AERONET-A federated instrument network and data archive for aerosol characterization. Remote Sensing of Environment 66, 1-16.

Hsu, N.C., Herman, J.R., Bhartia, P.K., Seftor, C.J., Torres, O., Thompson, A.M. Gleason, J.F., Eck, T.F., Holben, B.N., 1996. Detection of biomass burning smoke from TOMS measurements. Geophysical Research Letters 23, 745-748.

Hsu, N.C., Herman, J.R., Gleason, J.F., Torres, O., Seftor, C.J., 1999. Satellite detection of smoke aerosols over a snow/ice surface by TOMS. Geophysical Research Letters 26 (8), 1165-1168. http://dx.doi.org/10.1029/1999GL900155.

Hsu, N.C., Herman, J.R., Tsay, S.-C., 2003. Radiative impacts from biomass burning in the presence of clouds during boreal spring in Southeast Asia. Geophysical Research Letters 30 (5), 1224. http://dx.doi.org/10.1029/2002GL016485.

Hsu, N.C., Tsay, S.-C., King, M.D., Herman, J.R., 2004. Aerosol properties over brightreflecting source regions. IEEE Transactions on Geoscience and Remote Sensing 42, 557-569.

Hsu, N.C., Tsay, S.-C., King, M.D., Herman, J.R., 2006. Deep-blue retrievals of Asian aerosol properties during ACE-Asia. IEEE Transactions on Geoscience and Remote Sensing 44, 3180-3195. http://dx.doi.org/10.1029/2005JD006549.

Hsu, N.C., Gautam, R., Sayer, A.M., Bettenhausen, C., Li, C., Jeong, M.J., Tsay, S.-C., Holben, B.N., 2012. Global and regional trends of aerosol optical depth over land and ocean using SeaWiFS measurements from 1997 to 2010. Atmospheric Chemistry and Physics 12, 8037-8053. http://dx.doi.org/10.5194/acp-12-8037-2012.

Huang, J., Hsu, N.C., Tsay, S.-C., Jeong, M.J., Holben, B.N., Berkoff, T.A., Welton, E.J., 2011. Susceptibility of aerosol optical thickness retrievals to thin cirrus contamination during the BASE-ASIA campaign. Journal of Geophysical Research Atmospheres 116, D08214. http://dx.doi.org/10.1029/2010JD014910.

Huang, K., Fu, J.S., Hsu, N.C., Gao, Y., Dong, X., Tsay, S.-C., Lam, Y.F., 2013. Impact assessment of biomass burning on air quality in Southeast and East Asia during BASE-ASIA. Atmospheric Environment 78, 291-302.

Huffman, G.J., Adler, R.F., Bolvin, D.T., Gu, G., Nelkin, E.J., Bowman, K.P., Hong, Y., Stocker, E.F., Wolff, D.B., 2007. The TRMM multi-satellite precipitation analysis: quasi-global, multi-year, combined-sensor precipitation estimates at fine scale. Journal of Hydrometeorology 8 (1), 38-55.

Jaffe, D., Bertschi, I., Jaeglé, L., Novelli, P., Reid, J.S., Tanimoto, H., Vingarzan, R. Westphal, D.L., 2004. Long-range transport of Siberian biomass burning emissions and impact on surface ozone in western North America. Geophysical Research Letters 31, L16106. http://dx.doi.org/10.1029/2004GL020093.

Janjai, S., Suntaropas, S., Nunez, M., 2009. Investigation of aerosol optical properties in Bangkok and suburbs. Theoretical Applied Climatology 96, 221-233. http:// dx.doi.org/10.1007/s00704-008-0026-4682-691.

Janjai, S., Nunez, M., Masiri, I., Wattan, R., Buntoung, S., Jantarach, T., Promsen, W. 2012. Aerosol optical properties at four sites in Thailand. Atmospheric and Climate Sciences 2 (4), 441-453. http://dx.doi.org/10.4236/acs.2012.24038. 
Ji, Q., Tsay, S.-C., 2010. A novel non-intrusive method to resolve the thermal-domeeffect of pyranometers: instrumentation and observational basis. Journal of Geophysical Research - Atmospheres 115, D00K21. http://dx.doi.org/10.1029/ 2009JD013483.

Ji, Q., Tsay, S.-C., Lau, K.-M., Hansell, R.A., Butler, J.J., Cooper, J.W., 2011. A novel nonintrusive method to resolve the thermal-dome-effect of pyranometers: radiometric calibration and implications. Journal of Geophysical Research 116, D24105. http://dx.doi.org/10.1029/2011JD016466.

Klein, S.A., Hartmann, D.L., 1993. The seasonal cycle of low stratiform clouds. Journal of Climate 6, 1587-1606.

Koren, I., Kaufman, Y.J., Remer, L.A., Martins, J.V., 2004. Measurement of the effect of Amazon smoke on inhibition of cloud formation. Science 303 (5662), 13421345. http://dx.doi.org/10.1126/science.1089424.

Lau, K.-M., Yang, S., 1997. Climatology and interannual variability of the Southeast Asian summer monsoon. Advances in Atmospheric Sciences 14, 141-162.

Lawrence, M.G., Lelieveld, J., 2010. Atmospheric pollutant outflow from southern Asia: a review. Atmospheric Chemistry and Physics 10, 11017-11096. http:// dx.doi.org/10.5194/acp-10-11017-2010.

Levy, R.C., Remer, L., Mattoo, S., Vermote, E., Kaufman, Y.J., 2007. Second-generation algorithm for retrieving aerosol properties over land from MODIS spectral reflectance. Journal of Geophysical Research - Atmospheres 112, D13211. http:// dx.doi.org/10.1029/2006JD007811.

Li, C., Tsay, S.-C., Hsu, N.C., Kim, J.Y., Howell, S.G., Huebert, B.J., Ji, Q., Jeong, M.-J., Wang, S.-H., Hansell, R.A., Bell, S.W., 2013. Characteristics and composition of atmospheric aerosols in Phimai, Central Thailand during BASE-ASIA. Atmospheric Environment 78, 60-71.

Lim, Y.-K., Kim, K.-Y., 2007. ENSO impact on the space-time evolution of the regional Asian summer monsoons. Journal of Climate 20, 2397-2415.

Lin, N.-H., Tsay, S.-C., Reid, J.S., Yen, M.-C., Sheu, G.R., Wang, S.-H., Chi, K.-H., Chuang, M.-T., Ou Yang, C.-F., Fu, J.S., Lee, C.-T., Wang, L.-C., Wang, J.-L., Hsu, C.N., Holben, B.N., Chu, Y.-C., Maring, H.B., Nguyen, A.X., Sopajaree, K., Chen, S.-J., Cheng, M.-T., Tsuang, B.-J., Tsai, C.-J., Peng, C.-M., Chang, C.-T., Lin, K.-S., Tsai, Y.-I., Lee, W.-J., Chang, S.-C., Liu, J.-J., Chiang, W.-L., 2013. An overview of regional experiments on biomass burning aerosols and related pollutants in Southeast Asia: from BASE-ASIA and Dongsha Experiment to 7-SEAS. Atmospheric Environment 78, 1-19.

Loftus, A.M., 2012. A Triple-moment Bulk Hail Microphysics Scheme to Investigate the Sensitivities of Hail to Aerosols. Ph.D. dissertation, Dept. of Atmospheric Science, Colorado State Univ., 410 pp. Available at: http://digitool.library. colostate.edu/R/.

Martin, S.T., Andreae, M.O., Artaxo, P., Baumgardner, D., Chen, Q., Goldstein, A.H., Guenther, A., Heald, C.L., Mayol-Bracero, O.L., McMurry, P.H., Pauliquevis, T., Pöschl, U., Prather, K.A., Roberts, G.C., Saleska, S.R., Silva Dias, M.A., Spracklen, D.V., Swietlicki, E., Trebs, I., 2010. Sources and properties of Amazonian aerosol particles. Reviews of Geophysics 48, RG2002. http://dx.doi.org/ 10.1029/2008RG000280.

Milbrandt, J.A., Yau, M.K., 2005. A multimoment bulk microphysics parameterization. Part II: a proposed three-moment closure and scheme description. Journal of the Atmospheric Sciences 62, 3065-3081.

Patadia, F., Gupta, P., Christopher, S.A., Reid, J.S., 2008. A multisensor satellite-based assessment of biomass burning aerosol radiative impact over Amazonia. Journal of Geophysical Research - Atmospheres 113, D12214. http://dx.doi.org/10.1029/ 2007JD009486.

Perlwitz, J., Miller, R.L., 2010. Cloud cover increase with increasing aerosol absorptivity: a counterexample to the conventional semidirect aerosol effect. Journal of Geophysical Research - Atmospheres 115, D08203. http://dx.doi.org/ 10.1029/2009JD012637.

Peters, K., Quaas, J., Graßl, H., 2011. A search for large-scale effects of ship emissions on clouds and radiation in satellite data. Journal of Geophysical Research Atmospheres 116, D24205. http://dx.doi.org/10.1029/2011JD016531.

Prospero, J.M., Lamb, J.P., 2003. African droughts and dust transport to the Caribbean: climate change and implications. Science 302, 1024-1027.

Ramanathan, V., Crutzen, P.J., 2003. New directions: atmospheric brown clouds. Atmospheric Environment 37, 4033-4035.

Ramanathan, V., Crutzen, P.J., Kiehl, J.T., Rosenfeld, D., 2001. Aerosols, climate, and the hydrological cycle. Science 294, 2119-2124.

Ramanathan, V., Chung, C., Kim, D., Bettge, T., Buja, L., Kiehl, J.T., Washington, W.M., Fu, Q., Sikka, D.R., Wild, M., 2005. Atmospheric brown clouds: impacts on South Asian climate and hydrological cycle. Proceedings of National Academy of Sciences U. S. A. 102, 5326-5333.

Reid, J.S., Koppmann, R., Eck, T.F., Eleuterio, D.P., 2005a. A review of biomass burning emissions part II: intensive physical properties of biomass burning particles. Atmospheric Chemistry and Physics 5, 799-825.

Reid, J.S., Eck, T.F., Christopher, S.A., Koppmann, R., Dubovik, O., Eleuterio, D.P., Holben, B.N., Reid, E.A., Zhang, J., 2005b. A review of biomass burning emissions part III: intensive optical properties of biomass burning particles. Atmospheric Chemistry and Physics 5, 827-849.

Reid, J.S., Hyer, E.J., Prins, E.M., Westphal, D.L., Zhang, J., Wang, J., Christopher, S.A., Curtis, C.A., Schmidt, C.C., Eleuterio, D.P., Richardson, K.A., Hoffman, J.P., 2009. Global monitoring and forecasting of biomass-burning smoke: description of and lessons from the Fire Locating And Modeling of Burning Emissions
(FLAMBE) program. IEEE Journal of Selected Topics in Applied Earth Observations and Remote Sensing 2, 144-162.

Reid, J.S., Hyer, E.J., Johnson, R.S., Holben, B.N., Yokelson, R.J., Zhang, J., Campbell, J.R., Chrxistopher, S.A., Di Girolamo, L., Giglio, L., Holz, R.E., Kearney, C., Miettinen, J., Reid, E.A., Turk, F.J., Wang, J., Xian, P., Zhao, G., Balasubramanian, R., Chew, B.N., Janjai, S., Lagrosas, N., Lestari, P., Lin, N.-H., Mahmud, M., Nguyen, A.X., Norris, B., Oahn, N.T.K., Oo, M., Salinas, S.V., Welton, E.J., Liew, S.C., 2012. Observing and understanding the Southeast Asian aerosol system by remote sensing: an initial review and analysis for the Seven Southeast Asian Studies. Atmospheric Research. http://dx.doi.org/10.1016/j.atmosres.2012.06.005.

Sano, I., Mukai, S., Yamano, M., Takamura, T., Nakajima, T., Holben, B.N., 2003. Calibration and validation of retrieved aerosol properties based on AERONET and SKYNET. Advances Space Research 32, 2159-2164.

Sayer, A.M., Hsu, N.C., Bettenhausen, C., Ahmad, Z., Holben, B.N., Smirnov, A. Thomas, G.E., Zhang, J., 2012a. SeaWiFS Ocean Aerosol Retrieval (SOAR): algorithm, validation, and comparison with other data sets. Journal of Geophysical Research - Atmospheres 117, D03206. http://dx.doi.org/10.1029/2011JD016599.

Sayer, A.M., Hsu, N.C., Bettenhausen, C., Jeong, M.-J., Holben, B.N., Zhang, J., 2012b. Global and regional evaluation of over-land spectral aerosol optical depth retrievals from SeaWiFS. Atmospheric Measurements Techniques 5, 1761-1778. http://dx.doi.org/10.5194/amt-5-1761-2012.

Sorooshian, A., Feingold, G., Lebsock, M.D., Jiang, H.L., Stephens, G.L., 2009. On the precipitation susceptibility of clouds to aerosol perturbations. Geophysical Research Letters 36, L13803. http://dx.doi.org/10.1029/2009GL038993.

Stephens, G.L., Tsay, S.-C., Stackhouse Jr., P.W., Flatau, P.J., 1990. The relevance of the microphysical and radiative properties of cirrus clouds to climate and climatic feedback. Journal of the Atmospheric Sciences 47, 1742-1753.

Stevens, B., Feingold, G., 2009. Untangling aerosol effects on clouds and precipitation in a buffered system. Nature 461 (7264), 607-613.

Streets, D.G., Yarber, K.F., Woo, J.-H., Carmichael, G.R., 2003. Biomass burning in Asia: annual and seasonal estimates and atmospheric emissions. Global Biogeochemical Cycles 17 (4), 1099. http://dx.doi.org/10.1029/2003GB002040.

Swap, R.J., Annegarn, H.J., Suttles, J.T., King, M.D., Platnick, S., Privette, J.L., Scholes, R.J., 2003. Africa burning: a thematic analysis of the Southern African Regional Science Initiative (SAFARI 2000). Journal of Geophysical Research 108 (D13), 8465. http://dx.doi.org/10.1029/2003JD003747.

Tao, W.-K., Simpson, J., Baker, D., Braun, S., Chou, M.-D., Ferrier, B., Johnson, D., Khain, A., Lang, S., Lynn, B., Shie, C.-L., Starr, D., Sui, C.-H., Wang, Y., Wetzel, P., 2003. Microphysics, radiation and surface processes in the Goddard Cumulus Ensemble (GCE) model. Meteorology and Atmospheric Physics 82, 97-137.

Twomey, S.A., Piepgrass, M., Wolfe, T.L., 1984. An assessment of the impact of pollution on the global albedo. Tellus $36,356-366$.

van der Werf, G.R., Randerson, J.T., Giglio, L., Collatz, G.J., Mu, M., Kasibhatla, P.S., Morton, D.C., DeFries, R.S., Jin, Y., van Leeuwen, T.T., 2010. Global fire emissions and the contribution of deforestation, savanna, forest, agricultural, and peat fires (1997-2009). Atmospheric Chemistry and Physics 10, 11707-11735. http:// dx.doi.org/10.5194/acp-10-11707-2010.

Wang, S.-H., Tsay, S.-C., Lin, N.-H., Hsu, N.C., Bell, S.W., Li, C., Ji, Q., Jeong, M.-J., Hansell, R.A., Welton, E.J., Holben, B.N., Sheu, G.-R., Chu, Y.-C., Chang, S.-C., Liu, J.-J., Chiang, W.-L., 2011. First detailed observations of long-range transported dust over the northern South China Sea. Atmospheric Environment 45, 4804-4808.

Wang, S.-H., Hsu, N.C., Tsay, S.-C., Lin, N.-H., Sayer, A.M., Huang, S.-J., Lau, K.-M., 2012. Can Asian dust trigger phytoplankton blooms in the oligotrophic northern South China Sea? Geophysical Research Letters 39. http://dx.doi.org/10.1029/ 2011GL050415.

Wang, S.-H., Tsay, S.-C., Lin, N.-H., Chang, S.-C., Li, C., Welton, E.J., Holben, B.N., Hsu, N.C., Lau, K.-M., Lolli, S., Kuo, C.-C., Chia, H.-P., Chiu, C.-Y., Lin, C.-C., Bell, S.W., Ji, Q., Hansell, R.A., Sheu, G.R., Chi, K.-H., Peng, C.-M., 2013. Origin, transport, and vertical distribution of atmospheric pollutants over the northern South China Sea during 7-SEAS/Dongsha experiment. Atmospheric Environment 78, 124-133.

Wen, G., Marshak, A., Cahalan, R.F., Remer, L.A., Kleidman, R.G., 2007. 3-D aerosolcloud radiative interaction observed in collocated MODIS and ASTER images of cumulus cloud fields. Journal of Geophysical Research - Atmospheres 112, D13204. http://dx.doi.org/10.1029/2006JD008267.

Wilcox, E.M., 2012. Direct and semi-direct radiative forcing of smoke aerosols over clouds. Atmospheric Chemistry and Physics 12, 139-149. http://dx.doi.org/ 10.5194/acp-12-139-2012.

Wild, M., 2009. Global dimming and brightening: a review. Journal of Geophysical Research - Atmospheres 114, D00D16. http://dx.doi.org/10.1029/2008JD011470.

World Meteorological Organization (WMO), 2008. Guide to Meteorological Instruments and Methods of Observation, seventh ed. WMO-No.8, World Meteorological Organization, Geneva, ISBN 978-92-63-100085.

Yokelson, R.J., Karl, T., Artaxo, P., Blake, D.R., Christian, T.J., Griffith, D.W.T., Guenther, A., Hao, W.M., 2007. The tropical forest and fire emissions experiment: overview and airborne fire emission factor measurements. Atmospheric Chemistry and Physics 7, 5175-5196.

Yu, H., Fu, R., Dickinson, R.E., Zhang, Y., Chen, M., Wang, H., 2007. Interannual variability of smoke and warm cloud relationships in the Amazon as inferred from MODIS retrievals. Remote Sensing of Environment 111 (4), 435-449. http:// dx.doi.org/10.1016/j.rse.2007.04.003. 